\title{
DO HIGHER SALARIES BUY BETTER TEACHERS?
}

\author{
Eric A. Hanushek \\ John F. Kain \\ Steven G. Rivkin
}

\author{
Working Paper 7082 \\ http://www.nber.org/papers/w7082 \\ NATIONAL BUREAU OF ECONOMIC RESEARCH \\ 1050 Massachusetts Avenue \\ Cambridge, MA 02138 \\ April 1999
}

This paper was prepared for the annual meetings of the American Economic Association, New York, January 3-5, 1999. Helpful comments were provided by Susanna Loeb and seminar participants at the National Bureau of Economic Research and the University of California, Berkeley. Hanushek and Rivkin thank the Donner Foundation and the Smith Richardson Foundation for funding, and Kain thanks the Smith Richardson Foundation and the Spencer Foundation. The views expressed in this paper are those of the authors and do not reflect those of the National Bureau of Economic Research.

1999 by Eric A. Hanushek, John F. Kain, and Steven G. Rivkin. All rights reserved. Short sections of text, not to exceed two paragraphs, may be quoted without explicit permission provided that full credit, including ${ }^{\circ}$ notice, is given to the source. 
Do Higher Salaries Buy Better Teachers?

Eric A. Hanushek, John F. Kain, and Steven G. Rivkin

NBER Working Paper No. 7082

April 1999

JEL No. I2, J4

\begin{abstract}
Important policy decisions rest on the relationship between teacher salaries and the quality of teachers, but the evidence about the strength of any such relationship is thin. This paper relies upon the matched panel data of the UTD Texas School Project to investigate how shifts in salary schedules affect the composition of teachers within a district. The panel data permit separation of shifts in salary schedules from movement along given schedules, and thus the analysis is much more closely related to existing policy proposals. In analyses both of teacher mobility and of student performance, teacher salaries are shown to have a modest impact. Teacher mobility is more affected by characteristics of the students (income, race, and achievement) than by salary schedules. Salaries are also weakly related to performance on teacher certification tests - appearing to be relevant only in districts doing high levels of hiring, but preliminary examination shows that the certification tests are not significantly related to student achievement. The only significant relationship between salaries and student achievement holds (implausibly) for existing experienced teachers and not for new hires or for probationary teachers.
\end{abstract}

Eric A. Hanushek

University of Rochester

Wallis Institute of Political Economy

Rochester, NY 14627-0158

and NBER

hanu@troi.cc.rochester.edu
John Kain

University of Texas at Dallas

Green Ctr. for Study of Science and Society P.O. Box 830688

Richardson, TX 75083-0688

jkain@utdallas.edu

Steven G. Rivkin

Amherst College

Department of Economics

Amherst, MA 01002

sgrivkin@amherst.edu 


\title{
Do Higher Salaries Buy Better Teachers?
}

\author{
by Eric A. Hanushek, John F. Kain, and Steven G. Rivkin
}

Do higher salaries raise the quality of teaching? Many influential reports and proposals advocate substantial salary increases as a means of attracting and retaining more talented teachers in the public schools and of encouraging harder work by current teachers. Salary policies have also been cited as important for offsetting changes in demands outside of schools and for dealing with the potentially unattractive working conditions often identified in central city schools.

The empirical evidence on the link between teacher quality and pay is, however, decidedly mixedraising doubts that there is a strong relationship between the two. Direct analyses of student achievement, for example, provide limited evidence of any systematic relationship. Two explanations have emerged in response to this evidence. On the one hand, some argue that the true relationship between teacher quality and salaries is quite strong, but methodological and data problems have impeded the identification of salary effects. Others take a less sanguine position, arguing that the evidence captures accurately the weak performance incentives in the public schools that lead administrators to make hiring and retention decisions that are not strongly linked with teacher quality. ${ }^{1}$ The evidence is quite strong on one point: teacher quality is an important determinant of achievement (e.g., Rivkin, Hanushek, and Kain 1998).

There are four main methodological problems that impede the estimation of the true relationship between teacher quality and salaries. Perhaps the most important is the difficulty of measuring teacher quality, because both direct measures of teacher characteristics and indirect measures based on student performance have proved problematic. Secondly, understanding the effects of salary policies requires distinguishing between shifts in salary schedules and movements along a given schedule (with, for example, increases in teacher experience), but this has proved generally difficult to do in past empirical work.

${ }^{1}$ Loeb and Page (1998) emphasize the difficulty of identifying salary effects, and argue that methodological problems lead to inconsistent estimates of the relationship between quality and pay. On the other side, Ballou and Podgursky (1997) provide evidence that school administrators do not hire the best teaching candidates, thereby weakening the link between quality and pay. 
Thirdly, because of tenure arrangements and the reluctance of schools to hire older teachers, the teacher labor market is far from fluid, and the entire recent history of pay levels in addition to current pay influence the composition of teachers. Finally, the likely existence of compensating differentials for different working conditions complicates the interpretation of observed salary differentials across districts and states.

This paper employs a unique matched panel data set of teachers and students in Texas in an effort to understand more fully the dynamics of the teacher labor market and the true impact of salaries on teacher quality. The multiple cohorts of students and teachers, complete with repeated student achievement measures and teacher test scores, are particularly useful for addressing the key methodological issues.

The empirical analysis is divided into two interrelated parts. In part one, we study the relationship among mobility, district pay and other district characteristics by investigating the determinants of transitions both between and out of Texas public schools. The pattern of teacher transitions provides strong evidence that teachers prefer particular student characteristics and somewhat weaker evidence that salaries affect transitions, particularly when compensating factors are taken into account. Nevertheless, because it is quite difficult to isolate the labor supply relationships from demand side influences, the transition results are not clear estimates of the causal link between pay, student demographics and the supply of teachers.

In part two we examine the relationship between teacher quality and pay. The finding that mobility is partially related to pay suggests that teachers respond to pay differences, but the crucial question is whether districts select higher quality teachers when the applicant pool expands. Currently little is known about selection rules of schools and how they interact with teacher supply. We utilize two separate approaches in an effort to identify fundamental features of the quality/salary relationship. First, we estimate the relationship between teacher test scores and starting salaries for four cohorts of new teachers using district fixed effects. This methodology has the advantage that past salary levels are not relevant to the quality of first year teachers but the disadvantage that teacher test scores may not be a good measure of quality. Second, we directly estimate the relationship between student achievement and district salary 
schedules using both district and student fixed effects and controlling for student demographics.

Importantly, we concentrate on differences among salary schedules as distinct from movements along given schedules. Overall, the results provide little support for the hypothesis that pay is an important determinant of teacher quality. This finding is consistent with previous work on Texas schools that finds the majority of variation in education quality exists within rather than between schools and therefore cannot be closely linked with pay and other district or school wide factors.

\section{Salaries and the Supply of Teacher Quality}

The standard microeconomic framework for analyzing teacher supply and salaries would began with individual labor supply decisions and aggregate these up to a market supply function. The supply of labor to district $\mathrm{d}$ within a geographical area $\mathrm{j}$ can be characterized by:

$$
q_{d j}^{S}=f\left(w_{d}, W C_{d}, A_{j}, O_{j}\right)
$$

where $\mathrm{q}^{\mathrm{S}}$ is the supply of teacher quality for district $\mathrm{d}$ in area $\mathrm{j} ; \mathrm{w}_{\mathrm{d}}$ and $\mathrm{WC}_{\mathrm{d}}$ are wages and working conditions, respectively, in district $\mathrm{d}$; and $\mathrm{A}_{\mathrm{j}}$ and $\mathrm{O}_{\mathrm{j}}$ are amenities and other employment opportunities, respectively, in area $\mathrm{j}$.

The other half of the market, by simple analogy to the theory of the firm, has schools making maximizing decisions such as:

$$
\begin{gathered}
\max \sum_{i} P_{d i \text { subject to }} \\
P_{d i}=g\left(q_{d}, X_{d}, F_{d i}\right) \text { [production function] } \\
B_{d}=w_{d}\left(q_{d}\right)+p_{x} X_{d} \text { [budget constraint] }
\end{gathered}
$$


where $\Sigma \mathrm{P}$ is aggregate performance in district $\mathrm{d}$ across its students, $\mathrm{i}$; $\mathrm{X}$ includes all other purchased inputs to schooling; $F$ is the family and peer inputs for district d; B is the district's budget constraint; and $\mathrm{p}_{\mathrm{x}}$ is the price of purchased inputs. Solving this maximization problem would provide the demand by district $\mathrm{d}$ for teacher quality as a function of wages and a host of other factors.

$$
q_{d}^{D}=g\left(w_{d j}, \ldots\right) \text { [teacher demand] }
$$

Unfortunately, both anecdotal and empirical evidence raise doubts about the conception of schools as classic outcome maximizers. First, there are serious questions about the objective function of schools, i.e., what is being maximized. A benign form of this is typified by Brown and Saks (1973), who posit that schools have preferences not only for average achievement but also for the distribution of achievement. A less benign form would be a bureaucratic model (such as Niskanen 1971, 1975; Blais and Dion 1991) which has school personnel maximizing budget or some other aspects of organization or resources, where student achievement is not the primary focus. Second, the existence of state regulations or union contracts with restrictive conditions could inhibit the optimization approach of schools. State teacher certification requirements, tenure, salary profiles that differ from marginal productivity, and restrictions on other inputs such as binding maximum class sizes are each examples of factors that could bound schools away from the optimum. Third, at a basic level school decision makers may not fully understand the production function and the effectiveness of different inputs. Consequently, rather than thinking of the labor demand functions that would come out of a structure that optimizes aggregate achievement, it may be better to think of a selection rule for teachers that combines various elements of the objectives of teachers and schools, of districts' ability to judge teacher quality, and of the characteristics of the local labor market.

Regardless of whether schools act to maximize achievement or pursue other objectives, it is quite difficult to identify separately the labor supply and demand (or selection) functions. Though we attempt to 
draw inferences about supply responses from the observed pattern of teacher transitions, ultimately it is the combination of supply and demand that determines the link between quality and pay.

To fix the interpretation of the subsequent empirical work, we discuss briefly the most common issues that arise in the investigation of teacher labor markets, and outline the approach used in this analysis. Equation (1) describes the framework within which we examine these supply and demand side factors:

$$
q_{d}^{*}=h\left(w_{d}^{*}, H_{d}, W C_{d}, A_{j}, O_{j}, L_{d j}\right)
$$

where $\mathrm{H}$ captures district hiring and retention practices and L captures worker skills and preferences and an asterisk indicates the observed outcomes of teacher quality and wage decisions.

Teacher quality $(q)$. Fundamental to all discussions of teacher labor markets and teacher salary policies is the absence of clean measures of teacher quality. Available evidence indicates that direct measures of teacher quality, based on schooling, experience, college attended or even teacher test scores account for little of the variation in classroom performance (Hanushek 1997). This is not to say that these measures have no explanatory power, and Ferguson (1991) and Ehrenberg and Brewer (1994) both find that measured performance on teacher tests and college selectivity are systematically related to student achievement, with test scores having the strongest link. ${ }^{2}$

An alternative strategy uses information on student achievement itself as an indirect measure of teacher quality. The finding that teacher salaries have a significant impact on student achievement would imply that they have a significant effect on teacher quality. This strategy has great appeal, because it circumvents the problem of identifying the specific teacher characteristics that measure quality. However,

\footnotetext{
${ }^{2}$ The evidence suggests that test scores provide more information about teacher quality than either college selectivity or highest degree earned. Test scores have been used to measure the quality of people training to be teachers (Weaver 1983; Manski 1987; Murnane et al, 1991; Hanushek and Pace 1995; Strauss 1998). Such test measures are frequently related to state requirements for teacher certification and even for entry into teacher training programs (see Strauss 1998).
} 
use of student achievement measures introduces a separate set of issues, and the inconclusive evidence on the effects of salaries on achievement is often attributed to shortcomings of data and methodology. ${ }^{3}$

In this paper we use both teacher test scores and student achievement to identify the relationship between quality and salaries. Two certification tests are taken by the majority of new elementary school teachers, and these tests are used as direct measures of quality. In the analysis of student achievement, the availability of repeated test score observations permits the use of fixed effects models that control for unobserved differences in the rate at which students acquire skills, and the large amount of information on schools can be used to control for school influences on achievement other than salaries.

Salaries $\left(w_{d}\right)$. A fundamentally important issue in the consideration of teacher labor markets is which salary differences to look at and how they should be interpreted. ${ }^{4}$ At any point in time, teacher wages will vary within a district. These wage differences reflect different components of teacher salary contracts involving experience, graduate education levels, and a variety of other factors. Observing these wage differences provides information about movements along a supply schedule, but it does not provide information about what would happen if the entire salary schedule were shifted. Much of the analysis of achievement effects of salaries, for example, has considered differences in wages along a salary schedule or combined movements along schedules with changes in the overall salary structure (Hanushek 1997), while much of the policy debate focuses on the level of the entire salary schedule. ${ }^{5}$ A related consideration

${ }^{3}$ Loeb and Page (1998) emphasize the issue of compensating differentials; Betts (1996), Grogger (1996) and Hanushek, Rivkin and Taylor (1996) point to specification error introduced by omitted variables biases; and Card and Krueger (1997) focus on the appropriate measure of achievement.

${ }^{4}$ Fringe benefits are an important and growing share of compensation, and differences in the generosity of benefits is certainly not perfectly correlated with salary differences. Unfortunately, we, like all past researchers, do not have information on fringe benefits.

${ }^{5}$ There has also been a substantial amount of discussion about the use of teacher pay as a direct incentive for better performance by individual teachers. See Cohen and Murnane (1986) and Hanushek et al (1994) for discussions of merit pay. There is little evidence of systematic variation in salaries based on performance in Texas schools, although a number of districts are moving in that direction. 
involves intertemporal issues in the measurement of salaries. Rigidities in the teacher labor market mean that the history of salaries along with expectations for the future rather than just the current salary influence the existing stock of teachers. This is a particular problem for analyses that identify teacher salary effects by inter-temporal changes in salaries within states or districts, because past salaries undoubtably affect the current composition of teachers. ${ }^{6}$

By constructing annual salary schedules for single years of experience in each district over only teachers who do not have a graduate degree, we can isolate the effects of both cross-sectional and intertemporal variations in overall salary levels. ${ }^{7}$ Importantly, in the analysis of teacher test scores, we restrict the sample to new teachers thereby circumventing the difficulty of aggregating across the time path of district salary structures (cf. Murnane et al., 1991). The analysis of student achievement does use contemporaneous salaries, and the fixed effect specifications are identified on the basis of changes in salary over a short period of time. We perform a detailed sensitivity analysis in an effort to identify potential problems introduced by the use of panel data.

Hiring and Retention Policies $\left(H_{d}\right)$. While the relationship between salaries and employment is observed, it is not possible to infer a priori that the relationship is a "supply function" for teachers. Rather district hiring and retention practices are an important element in the labor market for teachers. This issue, made forcefully in a set of recent analyses (Ballou and Podgursky 1995, 1997 and Ballou 1996), is very important because it frames the interpretation of movements observed in the market. For example, the observation that retention and salaries are negatively related (controlling for all compensating differentials)

\footnotetext{
${ }^{6}$ Both Card and Krueger (1992) and Loeb and Page (1998) use state panels to identify the effects of salaries.

${ }^{7}$ We generally evaluate salary schedules at entry. Subsequently investigation shows that the results are not affected by considering salary differences for more experienced teachers. We have not investigated the possibility that salary increments for master's degrees vary systematically across districts.
} 
is consistent with a positively sloped supply curve and a positive relationship between salaries and the probability that districts will not rehire teachers.

The fact that districts may not hire and retain the best teachers does not eliminate the usefulness of studying the relationship between student achievement and salaries. It merely changes the interpretation to acknowledge that the results are conditional on personnel practices. However, to make inferences about salary effects on teacher labor markets, we must assume that the level or the rate of change of teacher salaries are not systematically related to the efficiency of personnel decisions. If this assumption is violated, a finding that salaries and achievement are positively related could simply result from high salaried districts having better administrators and not from any impact of salaries on the supply of teacher quality.

In this paper we use district fixed effects and other sample restrictions to remove any time invariant differences in hiring and retention procedures, such as those caused by differences in teacher representation. ${ }^{8}$ In addition, we include indicator variables for newly hired principals and superintendents in order to control for any systematic differences in hiring practices that accompany the change in administrators.

Alternative Earnings Opportunities and Amenities $\left(O_{j}, A_{j}\right)$. It is long established that one must account for differences in alternative opportunities for teachers. This is clearest in consideration of differential competition for specific teachers, say math and science teachers versus those in other specialities (e.g., Kershaw and McKean 1962; Zarkin 1985; Murnane et al., 1991). It also comes into play in terms of consideration of the set of districts that form the relevant decision set. If areas differ by prices or amenities or if labor markets are geographically confined, the salaries must be considered in comparison to the relevant set. This point, made by Chambers (1977) and Ferguson (1991), provides information on the

${ }^{8}$ Hoxby (1996) finds that the relationship between achievement and resources varies by district unionization status. In Texas, collective bargaining by teachers is prohibited by law, but this does not eliminate concerns about differential productivity across districts. 
specification of the wage and compensation comparisons. Important elements of the overall market factors are also highlighted in Flyer and Rosen (1997) and Boardman, Darling-Hammond, and Mullin (1982).

The empirical evidence supports the belief that alternative earnings opportunities affect teacher labor supply. In a series of papers, Dolton and van der Klaauw (forthcoming) and van der Klaaw (1997) investigate the impact of alternative opportunities on teacher transitions. They find evidence that opportunity wages affect the probabilities of both entry and exit. These results are consistent with earlier work by Murnane and Olsen $(1989,1990)$, which found that opportunity wages affected duration in teaching in both Michigan and North Carolina.

In this paper, differences in alternative wage opportunities are addressed in two different ways. First, a series of region and community type dummy variables that control for any geographic variation across Texas in the wage structure are included in the empirical specifications. Second, the inclusions of student and district fixed effects effectively removes any time invariant differences in opportunity wages. Working Conditions $\left(W C_{d}\right)$. Much has been made of the fact that there is more to a teaching job than just the overall salary or compensation levels. Some of the earliest work considered how teacher preferences might affect the selection of schools (Greenberg and McCall 1974; Murnane 1981). More generally, teachers might be willing to take lower salaries to obtain better conditions in their schools, a proposition first found in Antos and Rosen (1975) and subsequently pursued in a variety of other analyses (e.g., Baugh and Stone 1982). Some have interpreted the push for lower class sizes by teachers as reflecting an element of teacher compensation, as opposed to an educational policy designed to improve student achievement (cf. Grissmer and Kirby 1992).

If differences in working conditions are not accounted for and they are correlated with salaries, estimates of the relationship between achievement and salaries will confound salary influences with those of other factors that affect teacher labor supply. For example, if salaries are higher in urban districts and teachers prefer suburban districts, estimates of teacher salary effects on achievement confound the impacts 
of salary and community type unless adequate controls for community type are included. Loeb and Page (1998) argue that the failure to account for differences in working and labor market conditions explains why many studies fail to identify the true relationship between achievement and salaries.

A central element of the empirical analysis here is the description of movements of teachers across different types of schools and student populations in order to study the preferences of teachers and the form in which compensating wage differentials are played out. Four measures of student characteristics that may affect teacher labor supply are included: district percent low income, percent Black, percent Hispanic, and average student achievement score. These characteristics capture both temporal and cross-sectional differences in specifications that do not include district fixed effects, and changes over time in specifications that include fixed effects.

Worker Skills and Preferences $\left(L_{d j}\right)$. The discussions of alternative earnings opportunities and working conditions focused on differences in opportunities and constraints that teachers face, but it is also possible that worker productivity and preferences may vary geographically. For example, consider the case in which average skills of college graduates are higher in region 1 than region 2 and teachers are drawn from the same place in each region's skill distribution. In this case relative teacher salaries would be identical, but average teacher quality would be higher in region 1. A second example concerns preferences. Even if average skills, working conditions and relative wages are identical in two regions, one region may have higher quality teachers than another if there are differences in the value placed on the occupation of teacher. A third possibility arises if there are regional differences in the share of workers who teach.

The complications introduced by differences in skills and preferences may be substantial in crosssectional studies that make use of national data sets and in panel data sets with a number of years between observations. In the Texas data, however, removing regional means should capture differences in worker characteristics in specifications that do not include district fixed effects, and the fixed effects should account for any differences in worker characteristics that are significantly related to teacher salaries. 


\section{The Texas Database}

The ability to understand the character and outcomes of teacher labor market activities derives from the unique data base developed under the UTD Texas Schools Project, an undertaking conceived of and directed by John Kain. Working with the Texas Education Agency (TEA), this project has combined different data sources to compile matched panel data sets on students and teachers. The samples contain entire cohorts of Texas students and the universe of teachers in each year. While the data do not provide linkages of individual students and specific teachers, they do allow matching of students and teachers by school and grade for each year.

The Public Education Information Management System, TEA’s state-wide educational data base, reports key demographic data including race, ethnicity and gender for both students and teachers as well as student eligibility for a subsidized lunch. It also contains detailed annual information on teacher experience, salary, education, class size, grade, population served and subject. Importantly, this data base can be merged with information on both student and teacher achievement. Beginning in 1993, the Texas Assessment of Academic Skills (TAAS) was administered each spring to eligible students enrolled in grades three through eight. ${ }^{9}$ These criterion referenced tests, which evaluate student mastery of gradespecific subject matter, are merged with the student and teacher information. We concentrate on reading and mathematics performance, subjects that are examined in all grades. ${ }^{10}$

${ }^{9}$ Many special education students are exempted from the tests, as are other students for whom the test would not be educationally appropriate. In each year roughly 15 percent of students do not take the tests, either because of an exemption or because of repeated absences on testing days. We exclude participants in bilingual or special education programs from the achievement analysis. For an explicit analysis of the achievement of special education students, see Hanushek, Kain, and Rivkin (1998).

${ }^{10}$ Reading and math tests each contain approximately 50 questions, although the number of questions and average percent correctly answered varies across time and grades. We transform all test results into standardized scores with a mean of zero and variance equal to one. The bottom one percent of test scores and the top and bottom one percent of test score gains across years are trimmed from the sample in order to reduce measurement error. 
New teachers in Texas must take and eventually pass teacher certification tests. The majority of elementary school teachers examined in this study write two specific tests: the elementary school comprehensive test and the professional development test. Each is a criterion referenced test that focuses on pedagogy. We have transformed the scores into percentile measures to indicate better the location of school average teacher quality in the overall quality distribution.

Empirical salary schedules are constructed for each school district using the teacher microdata for the years 1993 to 1996 . Emphasis on district schedules reflects our interest in the effects of shifts in salary schedules. Each district's constructed salary schedule corresponds to the median salary of primary school teachers for the first ten single years of experience for all regular teachers without advanced degrees. The detailed panel data for each district and for individual teachers permit an unusual opportunity to address concerns about measurement error. ${ }^{11,12}$

\footnotetext{
${ }^{11}$ The cells for graduate degrees and for years of experience above ten become too thin in many districts to provide reliable salary information. We first employ median salaries because of concerns about coding errors leading to extreme values in salary. Further, we examined each district that experienced nominal median salary decreases either over time at any level of experience or across higher experience categories in any given year. We excluded individual teachers whose salary observations appeared to be unreflective of base salaries, but, if it was not possible to detect obvious errors, the district/experience/year cell was coded as missing. There was also substantial error in the teacher experience variable, exemplified by inconsistencies in reported experience for individual teachers over time. If a single year did not conform to an otherwise consistent string for an individual teacher, reported experience for that year was changed. Otherwise, reported experience was left unchanged. Error was also introduced by inconsistencies in district adjustments for part time teachers, and obvious mistakes were corrected.

${ }^{12}$ The salary information excludes a variety of special pay provisions for individual teachers. Districts offer a variety of individual extra pay opportunities, generally involving extra duties. Over 85 percent of the observed teachers receive no extra pay, and the median for those receiving it is approximately $\$ 1,000$. (Given the errors in reporting the salary data, however, our base pay measure may well include some portion of extra pay). While we do not address these issues here, it is possible that some districts regularly and openly reward individual teachers or groups of teachers through extra pay channels. In such a case, extra pay may provide additional incentives affecting labor market behavior. For 90 percent of all districts, less than a quarter of all teachers receive any extra pay. Nonetheless, for $3 \frac{1}{2} 2$ percent of the Texas districts, over half of the teachers receive some extra pay.
} 


\section{Teacher Mobility, Salaries and Student Demographics}

While teacher quality is known to be a primary determinant of student achievement, the leverage that a school district has to improve the stock and performance of its teachers through compensation, class size and other non-pecuniary job characteristics is surprisingly unclear. In a competitive achievementmaximizing system, the collection of compensation, resources, alternative employment opportunities and district amenities would interact to determine the allocation of teachers, and districts with the most to offer among competing schools would get the best teachers. But, available evidence raises questions about the quality of teacher selection, suggesting that the actual distribution of teacher quality reflects the variation in hiring and retention policies as well as ability to pay and to provide other amenities. ${ }^{13}$ We begin with an analysis of the patterns of teacher moves in order to sort out the relative attractiveness of different districts.

\section{Transitions Between and Within Districts (1993-96)}

A primary goal of our mobility analyses is sorting out the separate influences of salary and other determinants of job attractiveness. Teachers are observed moving within districts, between districts, and out of Texas public schools entirely annually between 1993 and 1996. Importantly, we have information about salaries and student characteristics for both the sending and receiving schools for each transition.

Similar to job turnover patterns for the labor market as a whole, transitions differ sharply by teacher experience. Table 1 indicates that mobility is much higher among probationary teachers $(0-2$ years of experience), who are almost twice as likely as prime age teachers (11-30 years experience) to exit Texas public schools and over four times as likely to switch districts. As expected, mobility picks up again as teachers near retirement age, and almost one fourth of teachers with over thirty years of experience leave

\footnotetext{
${ }^{13}$ For example, Ballou (1996) demonstrates that schools do not systematically choose applicants with the strongest academic backgrounds or cognitive abilities. Murnane et al. (1991) describes the high variance in the information obtained about applicants and in the selection procedures of districts.
} 
the Texas public schools each year. Overall 79 percent of teachers remain in the same school, 14 percent exit Texas public schools, ${ }^{14} 4$ percent change schools within districts, and 3 percent

Table 1. Year-to-year Transitions of Teachers by Experience, 1993-1996

\begin{tabular}{|c|c|c|c|c|c|}
\hline \multirow[b]{2}{*}{$\begin{array}{l}\text { Teacher } \\
\text { Experience }\end{array}$} & \multicolumn{4}{|c|}{ Percent of Teachers Who } & \multirow[b]{2}{*}{$\begin{array}{c}\text { Number of } \\
\text { teachers }\end{array}$} \\
\hline & $\begin{array}{l}\text { remain in } \\
\text { same school }\end{array}$ & $\begin{array}{l}\text { change } \\
\text { schools } \\
\text { within } \\
\text { same } \\
\text { district }\end{array}$ & $\begin{array}{l}\text { switch } \\
\text { districts }\end{array}$ & $\begin{array}{l}\text { exit Texas } \\
\text { public } \\
\text { schools }\end{array}$ & \\
\hline $0-2$ years & 71.2 & 5.0 & 5.8 & 18.0 & 73,261 \\
\hline 3-5 years & 75.1 & 4.8 & 4.1 & 15.9 & 55,072 \\
\hline 6-10 years & 79.2 & 4.6 & 2.8 & 13.5 & 60,831 \\
\hline $11-30$ years & 84.0 & 3.9 & 1.4 & 10.8 & 166,487 \\
\hline$>30$ years & 72.8 & 2.4 & 0.4 & 24.4 & 7,207 \\
\hline All & 79.1 & 4.3 & 2.9 & 13.7 & 376,078 \\
\hline
\end{tabular}

switch districts each year. This mobility is somewhat higher than national averages which indicate that 86 percent of all teachers remained in the same school, while only 6.6 percent left teaching between 1994 and 1995 (U.S. Department of Education, 1997). Part of the discrepancy is explicable. Our calculations for exiting from Texas public schools include people leaving teaching plus people teaching either in private

${ }^{14}$ While we observe all teacher movements within Texas public schools, any teacher entering a private school or leaving the state for public schools elsewhere is combined with teachers leaving the profession entirely. 
schools or outside of the state. The national patterns of mobility across experience categories do follow a similar pattern to that in Texas.

The pattern of moves tends to contradict the conventional wisdom that large urban districts are the proving ground for teachers, who move to suburban jobs when possible. Table 2, restricted to those changing districts, provides only weak support of the belief that teachers commonly leave urban districts for suburban positions. Among teachers in large urban districts, the majority of those switching 
Table 2. Destination Community Type for Teachers Changing Districts, by Origin Community Type and Teacher Experience Level

$\%$ of Teachers Who Move to

Origin Community

Type and Teacher

Experience

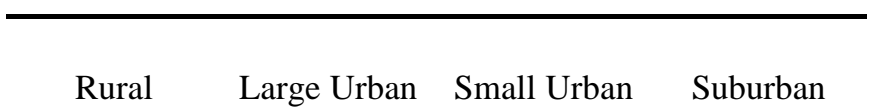

Number Teachers

Changing

Districts
Change in share

of teachers by community type 1993-1996

\section{All Teachers}

Rural

Large Urban

63.4

4.6

7.8

24.2

4,529

3.6

$-0.8$

20.8

11.6

9.6

58.0

1,359

1.9

0.8

Small Urban

28.8

10.6

12.8

47.8

1,184

2.4

3,786

2.7

Suburban

\section{Probationary Teachers (0-2 yrs experience)}

$\begin{array}{lccccrr}\text { Rural } & 58.5 & 5.3 & 8.1 & 28.1 & 1,803 & 8.0 \\ \text { Large Urban } & 16.4 & 11.2 & 10.6 & 61.7 & 517 & 3.8 \\ \text { Small Urban } & 25.3 & 11.8 & 13.2 & 49.7 & 509 & 5.2 \\ \text { Suburban } & 21.0 & 14.5 & 11.7 & 52.8 & 0.9\end{array}$


districts does relocate to suburban schools, but overall less than two percent of teachers in large urban districts move across districts in each year. The absolute number moving into urban districts is only slightly smaller than the number moving out. ${ }^{15}$

The bottom panel of Table 2 shows that a very similar pattern of movement holds for the subsample of probationary teachers, where again the net outflow from urban districts is small. Overall, probationary urban teachers are only one percentage point less likely to remain in the same school as probationary suburban teachers (71 versus 72 percent), and this is an identical gap to that for teachers of all experience levels. Two significant differences between new teachers starting in urban and starting in suburban districts do exist: Probationary urban teachers are roughly 3.5 percentage points more likely to exit teaching than teachers in suburban districts (not shown), while probationary suburban teachers are somewhat more likely simply to switch schools within districts.

Movement from rural districts follows a very distinct pattern. The majority of movers goes to a different rural district. Significantly fewer rural teachers move to urban districts than is the case for teachers initially in urban or suburban districts.

These aggregate transition rates among community types provide no information on the actual changes in salary and student composition. Tables 3,4 and 5 report in increasing detail the relationship between pre-move and post-move salaries and student characteristics for teachers who switch schools and districts. Each table concentrates on how the average of specific characteristics (C) change with a move from district $\mathrm{d}$ to district $\mathrm{d}$ ', calculated as

(2) $\Delta C_{d, d^{\prime}}=\overline{\left(C_{t}^{d^{\prime}}-C_{t}^{d}\right)}$

${ }^{15}$ During this period the share of Texas teachers in urban districts increased, implying that the small net outflow of teachers from urban districts is not simply a reflection of changes in the distribution of teaching positions across community types. 
where year $\mathrm{t}$ is the first year in the new district.

The salary changes are computed by single years of experience. For example, the salary change for a moving teacher with four years of experience equals the district average salary of 5th year teachers in the new district minus the district average salary of 5th year teachers in the old district, both calculated in the year of the change. Because consistent salary schedule information is only available for teachers with ten or fewer years of experience, all teachers with more experience are excluded from these tables. (Roughly three-fourths of teachers switching districts have less than 10 years of experience).

Table 3 reports change in salaries and district average student demographic characteristics by experience and gender. The top panel indicates that on average probationary teachers who move improve their salaries relative to what they would have earned in the initial district. Men gain 1.4 percent in salary with a move, while women gain half that amount. ${ }^{16}$ The average salary gain declines with experience, and the difference is statistically insignificant for more experienced teachers. ${ }^{17}$ The gain averaged across all movers with less than ten years of experience is 0.4 percent of annual salary at the time of the move.

Because compensating differentials could conceal the true change in salary holding other factors constant, we attempt to control for other determinants of teacher labor supply. Log salary at each experience level is regressed on 19 region dummies, 3 community type dummies, the district average

\footnotetext{
${ }^{16}$ Because women are more likely to be married or have children than men of the same age, the smaller gains of women may reflect the fact that more transitions are precipitated by family considerations. However, we have no information on reason for moving or family status.

${ }^{17}$ We present the analysis in terms of teacher experience, but tenure within the district may also have separate implications for salary and other factors that affect satisfaction and mobility.
} 
Table 3. Average Change in Salary and Student Characteristics for Teachers Changing Districts, by Gender and Experience

\begin{tabular}{|c|c|c|c|c|c|c|c|}
\hline & & men & & & women & & all \\
\hline & $\begin{array}{c}0-2 \text { years } \\
\text { experience }\end{array}$ & $\begin{array}{c}3-5 \text { years } \\
\text { experience }\end{array}$ & $\begin{array}{l}\text { 6-9 years } \\
\text { experience }\end{array}$ & $\begin{array}{c}0-2 \text { years } \\
\text { experience }\end{array}$ & $\begin{array}{c}3-5 \text { years } \\
\text { experience }\end{array}$ & $\begin{array}{l}\text { 6-9 years } \\
\text { experience }\end{array}$ & $\begin{array}{c}0-9 \text { years } \\
\text { experience }\end{array}$ \\
\hline $\begin{array}{l}\text { log base year } \\
\text { salary }\end{array}$ & $\begin{array}{c}0.014 \\
(0.004)\end{array}$ & $\begin{array}{c}0.009 \\
(0.005)\end{array}$ & $\begin{array}{l}-0.003 \\
(0.007)\end{array}$ & $\begin{array}{c}0.007 \\
(0.002)\end{array}$ & $\begin{array}{l}-0.002 \\
(0.002)\end{array}$ & $\begin{array}{l}-0.002 \\
(0.002)\end{array}$ & $\begin{array}{c}0.004 \\
(0.001)\end{array}$ \\
\hline $\begin{array}{l}\text { Salary } \\
\text { Residual }\end{array}$ & $\begin{array}{c}0.013 \\
(0.003)\end{array}$ & $\begin{array}{c}0.020 \\
(0.004)\end{array}$ & $\begin{array}{l}-0.002 \\
(0.006)\end{array}$ & $\begin{array}{c}0.007 \\
(0.001)\end{array}$ & $\begin{array}{c}0.004 \\
(0.002)\end{array}$ & $\begin{array}{l}-0.002 \\
(0.002)\end{array}$ & $\begin{array}{c}0.006 \\
(0.001)\end{array}$ \\
\hline District Averas & Characteri & & & & & & \\
\hline $\begin{array}{l}\text { Average Test } \\
\text { Score }\end{array}$ & $\begin{array}{l}0.064 \\
(0.01)\end{array}$ & $\begin{array}{l}0.074 \\
(0.02)\end{array}$ & $\begin{array}{l}0.036 \\
(0.02)\end{array}$ & $\begin{array}{l}0.087 \\
(0.01)\end{array}$ & $\begin{array}{l}0.092 \\
(0.01)\end{array}$ & $\begin{array}{l}0.075 \\
(0.01)\end{array}$ & $\begin{array}{l}0.080 \\
(0.00)\end{array}$ \\
\hline$\%$ Hispanic & $\begin{array}{l}-6.0 \\
(1.0)\end{array}$ & $\begin{array}{l}-6.2 \\
(1.5)\end{array}$ & $\begin{array}{l}-2.3 \\
(1.8)\end{array}$ & $\begin{array}{l}-5.2 \\
(0.4)\end{array}$ & $\begin{array}{l}-5.3 \\
(0.6)\end{array}$ & $\begin{array}{l}-4.2 \\
(0.6)\end{array}$ & $\begin{array}{l}-5.0 \\
(0.3)\end{array}$ \\
\hline$\%$ Black & $\begin{array}{l}-5.0 \\
(0.6)\end{array}$ & $\begin{array}{l}-2.2 \\
(0.9)\end{array}$ & $\begin{array}{c}0.5 \\
(1.1)\end{array}$ & $\begin{array}{l}-2.8 \\
(0.3)\end{array}$ & $\begin{array}{l}-2.9 \\
(0.4)\end{array}$ & $\begin{array}{l}-2.9 \\
(0.4)\end{array}$ & $\begin{array}{l}-2.6 \\
(0.2)\end{array}$ \\
\hline $\begin{array}{l}\% \text { Subsidized } \\
\text { Lunch }\end{array}$ & $\begin{array}{l}-6.0 \\
(0.9)\end{array}$ & $\begin{array}{l}-5.3 \\
(1.5)\end{array}$ & $\begin{array}{l}-2.4 \\
(1.7)\end{array}$ & $\begin{array}{l}-7.3 \\
(0.4)\end{array}$ & $\begin{array}{l}-2.4 \\
(0.6)\end{array}$ & $\begin{array}{l}-6.1 \\
(0.6)\end{array}$ & $\begin{array}{l}-6.6 \\
(0.3)\end{array}$ \\
\hline
\end{tabular}


achievement score, and the district average percentages of Black, Hispanic and low income students, ${ }^{18}$ The residuals from these regressions provide salary measures adjusted for differences in working conditions, amenities and local labor markets.

Consistent with the existence of compensating differentials, the second row of Table 3 shows that adjusted salaries increase by 50 percent more than raw salaries on average, though there is substantial variation in the pattern of results across experience and gender. Not surprisingly, the strongest support for presence of compensating differentials comes from teachers who move among urban and suburban districts. Table 4 shows that teachers who move from large urban to suburban schools experience average raw salary decreases of .65 percent but average adjusted salary increases of 1.4 percent. ${ }^{19}$ Similarly, the residual salary increase is three times as large as the raw salary increase for teachers who switch among suburban districts.

In contrast to the small changes in salary, the bottom panel of Table 3 provides strong evidence that teachers systematically favor higher achieving, non-minority, non-low income students. The findings for achievement are the clearest and most consistent across gender and experience categories, showing that the district average achievement rises by roughly .08 standard deviations for the average mover. The percentages Black, Hispanic and eligible for a subsidized lunch also decline for movers, though there is more variation across experience categories.

Similar to the pattern for salaries, Table 4 reveals dramatic changes in district average student characteristics for teachers who move from urban to suburban districts, including a 0.35 standard

\footnotetext{
${ }^{18}$ The achievement score is the average of math and reading scores. These regressions explain about 60 percent of the raw variance in log salaries, and the district student characteristics are significantly related to salaries. Standard errors in the tables have not been adjusted for the fact that these are residuals.

${ }^{19}$ The residual salaries control for interregional price differences but not for intraregional differences such as commonly observed housing price gradients. Thus, these estimates quite likely understate the fully compensated differences in salary.
} 
Table 4. Average Change in Salary and in District and Campus Student Characteristics for Teachers with 0-9 Years of Experience who Change Districts, by Community Type of Origin and Destination District

\begin{tabular}{|c|c|c|c|c|c|c|c|}
\hline \multirow[b]{2}{*}{$\begin{array}{l}\text { Origin } \\
\text { Community } \\
\text { Type }\end{array}$} & \multirow[b]{2}{*}{$\begin{array}{l}\text { Destination } \\
\text { Community } \\
\text { Type }\end{array}$} & \multirow[b]{2}{*}{$\begin{array}{l}\log \text { base } \\
\text { salary }\end{array}$} & \multirow[b]{2}{*}{$\begin{array}{l}\text { residual } \\
\text { salary }\end{array}$} & \multicolumn{4}{|c|}{ Average Student Characteristics } \\
\hline & & & & $\begin{array}{l}\text { test } \\
\text { score }\end{array}$ & $\begin{array}{c}\% \text { eligible } \\
\text { for subsidized } \\
\text { lunch }\end{array}$ & $\%$ Black & $\%$ Hispanic \\
\hline \multicolumn{8}{|c|}{ 1. District Average Characteristics } \\
\hline Large Urban & Suburban & $\begin{array}{l}-0.0065 \\
(0.0024)\end{array}$ & $\begin{array}{c}0.014 \\
(0.002)\end{array}$ & $\begin{array}{c}0.35 \\
(0.01)\end{array}$ & $\begin{array}{l}-23.9 \\
(0.9)\end{array}$ & $\begin{array}{l}-15.1 \\
(0.6)\end{array}$ & $\begin{array}{l}-18.8 \\
(0.9)\end{array}$ \\
\hline Suburban & Suburban & $\begin{array}{c}0.0021 \\
(0.0019)\end{array}$ & $\begin{array}{c}0.006 \\
(0.002)\end{array}$ & $\begin{array}{c}0.12 \\
(0.01)\end{array}$ & $\begin{array}{l}-9.5 \\
(0.6)\end{array}$ & $\begin{array}{l}-4.1 \\
(0.4)\end{array}$ & $\begin{array}{l}-7.0 \\
(0.6)\end{array}$ \\
\hline \multicolumn{8}{|c|}{ 2. Campus Average Characteristics } \\
\hline Large Urban & Suburban & & & $\begin{array}{c}0.34 \\
(0.02)\end{array}$ & $\begin{array}{l}-24.3 \\
(1.3)\end{array}$ & $\begin{array}{l}-15.5 \\
(1.3)\end{array}$ & $\begin{array}{l}-19.0 \\
(1.4)\end{array}$ \\
\hline Large Urban & $\begin{array}{l}\text { Large Urban } \\
\text { (same district) }\end{array}$ & & & $\begin{array}{c}0.13 \\
(0.01)\end{array}$ & $\begin{array}{l}-9.6 \\
(0.7)\end{array}$ & $\begin{array}{l}-3.4 \\
(0.8)\end{array}$ & $\begin{array}{l}-5.3 \\
(0.8)\end{array}$ \\
\hline
\end{tabular}


deviation rise in average achievement. Perhaps more surprising, teachers who move among suburban districts also experience similar, albeit smaller, changes in student characteristics than found in the urbansuburban moves: district average achievement rises by more than one tenth of a standard deviation, and the percentages Black, Hispanic and eligible for a subsidized lunch all decline.

The bottom panel of Table 4 calculates the changes in campus average student characteristics rather than district averages. There is little evidence in the first row of the panel that teachers who move from urban to suburban districts experience larger changes than the differential between district averages. In other words, urban-suburban movers appear to retain their same relative position in the two districts. On the other hand, teachers who move within urban districts experience a substantial increase in average achievement and a decline in percent minority and percent eligible for a subsidized lunch.

Distinct differences appear in the transition patterns of Black and Hispanic teachers. Table 5 reveals that Black teachers tend to move to schools with higher Black enrollment shares than the schools they left, regardless of whether they change districts or not. In addition, the change in average test scores is much smaller for Black and Hispanic Teachers. On the other hand, the average change in percent Hispanic experienced by Hispanic teachers is quite similar in direction and magnitude to the changes experienced by teachers as a whole. ${ }^{20}$

It is important to recognize that the changes in salaries and student demographics reflect both teacher preferences and district hiring and retention decisions. Because some teacher transitions result from involuntary job separations, these figures likely understate teacher preferences for both higher salaries and specific student characteristics.

\footnotetext{
${ }^{20}$ We look at annual changes, but Kain and Singleton (1996) show that these moving patterns accumulate and interact with new hiring to produce significant differences in teacher characteristics for Black and white students, even across campuses within individual districts.
} 
Table 5. Average Change in Salary and in District and Campus Student Characteristics for Black and Hispanic Teachers with 0-9 Years of Experience who Change Campuses

\begin{tabular}{|c|c|c|c|c|c|}
\hline \multirow[b]{2}{*}{$\begin{array}{c}\text { Race/ethnicity } \\
\text { of teacher }\end{array}$} & \multicolumn{4}{|c|}{ Average Student Characteristics } & \multirow[b]{2}{*}{$\begin{array}{c}\text { Number of } \\
\text { teachers } \\
\text { moving }\end{array}$} \\
\hline & $\begin{array}{l}\text { test } \\
\text { score }\end{array}$ & $\begin{array}{l}\% \text { eligible } \\
\text { for } \\
\text { subsidized } \\
\text { lunch }\end{array}$ & $\%$ Black & $\%$ Hispanic & \\
\hline
\end{tabular}

\section{Between Districts Moves}

$\begin{array}{lccccc}\text { Blacks } & -0.01 & -1.3 & 5.8 & -5.0 & 254 \\ & (0.03) & (1.9) & (2.5) & (1.9) & \\ \text { Hispanics } & & & & & \\ & 0.02 & -4.9 & 0.2 & -5.5 & 1,207 \\ & (0.01) & (0.8) & (0.5) & (0.9) & \end{array}$

\section{Within Districts Moves}

$\begin{array}{lccccc}\text { Blacks } & 0.01 & -4.0 & 3.8 & -6.0 & 464 \\ & (0.02) & (1.1) & (1.6) & (1.4) & \\ \text { Hispanics } & 0.03 & -5.3 & -0.7 & -2.8 & 1,360 \\ & (0.01) & (0.6) & (0.4) & (0.5) & \end{array}$

To summarize the effects on students, Table 6 reports simple school average transition rates at different points in the distribution of student and district characteristics. The table shows that teachers in schools in the top quartile of real salaries are 3 percentage points less likely to exit the public schools and almost 1 percentage point less likely to switch districts than teachers in the bottom quartile schools. Teachers in the top salary quartile are also somewhat less likely to switch schools within districts.

The most dramatic differences in school transition rates are related to student achievement. Teacher transition rates for schools in the bottom achievement quartile are much higher than those in the top quartile. Over 25 percent of teachers in the bottom quartile schools leave each year, while in the top quartile schools less than 20 percent leave. The largest difference is in the probability of exiting public schools entirely. These differences imply that the lowest achieving students are more likely to 
Table 6. School Average Transition Rates by Distribution of Residual Teacher Salary and Student Demographic Characteristics (data weighted by number of teachers in school)

\begin{tabular}{cccc} 
& Probability & Probability & Probability \\
quartile of & teachers & teachers & teachers \\
distribution & move to new & move to new & exit public \\
& school & district & schools \\
\hline
\end{tabular}

\section{Residual Salary}

$\begin{array}{llll}\text { 1st } & 5.0 \% & 3.3 \% & 16.7 \% \\ \text { 2nd } & 4.6 \% & 3.2 \% & 14.7 \% \\ \text { 3rd } & 4.9 \% & 2.8 \% & 14.2 \% \\ \text { 4th } & 4.2 \% & 2.5 \% & 13.7 \%\end{array}$

Average test score

1 st

$4.4 \%$

$3.8 \%$

$3.4 \%$

$17.4 \%$

2nd

$3.2 \%$

$3.6 \%$

$15.0 \%$

3rd

$3.3 \%$

$3.0 \%$

$14.1 \%$

4 th

$2.5 \%$

$12.7 \%$

\% elig for free lunch

$1 \mathrm{st}$

$3.8 \%$

$2.3 \%$

$12.8 \%$

2nd

$3.0 \%$

$3.3 \%$

$14.7 \%$

3rd

$3.4 \%$

$3.7 \%$

$15.0 \%$

4th

$4.7 \%$

$3.0 \%$

$16.6 \%$

\% Black

1 st

$3.4 \%$

$3.6 \%$

$16.2 \%$

2nd

$3.7 \%$

$2.7 \%$

$13.4 \%$

3rd

$3.6 \%$

$2.8 \%$

$13.6 \%$

4 th

$4.1 \%$

$3.3 \%$

$15.8 \%$

\% Hispanic

1 st

$3.3 \%$

$3.1 \%$

$14.1 \%$

2nd

$3.8 \%$

$3.1 \%$

$14.3 \%$

3rd

$3.5 \%$

$3.2 \%$

$14.7 \%$

4th

$4.3 \%$

$3.1 \%$

$16.5 \%$

Note: The quartile divisions are calculated using the number of teachers as weights for the size of each school. Differences in average class sizes imply that these weights do not exactly capture enrollment differences, but data on enrollment were not available for all schools in all years. 
have teachers new to the school and to the profession, and evidence from Texas strongly suggests that this will adversely affect achievement (Rivkin, Hanushek, and Kain, 1998).

\section{Transition Regressions}

The previous descriptive information on moves does not take into account the joint effects of the various influences. Table 7 presents reduced form estimates for linear models of the probability of leaving a district (either switching districts or exiting from the Texas public schools) as a function of the combined teacher and district characteristics. ${ }^{21}$ Separate estimates are computed by experience categories in order to allow for differences in preferences, family circumstances and job security. The direct salary effects are strongest for younger teachers: a 10 percent increase in salary is associated with a 2 percent decrease in the probability of leaving the district for probationary teachers and 1 percent decrease for teachers with 3 to 5 years of experience.

The multivariate analysis roughly follows the previously presented descriptive tables. Higher average student achievement significantly reduces the probability of moving or exiting Texas public schools at all levels of experience. Non-minority teachers are more likely to move the higher are the Black and Hispanic enrollment shares, although the only significant effects are related to percent Black students for younger teachers. Exactly the opposite is true for Black and Hispanic teachers, who are less likely to move the higher are these minority enrollment shares. There is little evidence of an independent effect of percent eligible for a subsidized lunch. Finally, (not shown) there is little or no evidence that the probability of moving is systematically related to average class size in any

\footnotetext{
${ }^{21}$ Note that these regressions expand the focus to include teachers who exit Texas public schools in addition to those who switch schools. In each year, more teachers exit than switch schools. All specifications other than those that include district fixed effects include region, community type and year dummies, school enrollment and average class size (measured for the available grades), number of campuses in a district, and teacher gender, race/ethnicity, experience and experience squared. The district fixed effect specifications drop the region and community type dummy variables.
} 
Table 7. Effects of District Base Salary and Student Characteristics on Probability of Leaving Current Campus, by Teacher Experience (Linear probability models with no district fixed effects; tstatistics in parentheses)

\begin{tabular}{lccccc} 
& \multicolumn{5}{c}{ teacher experience } \\
& $0-2$ yrs & $3-5$ yrs & $6-10$ yrs & $11-30$ yrs & $>30$ years \\
& & & & \\
log base year & -0.19 & -0.11 & -0.01 & -0.03 & 0.16 \\
salary & {$[-3.89]$} & {$[-2.18]$} & {$[-0.18]$} & {$[-0.75]$} & {$[0.91]$}
\end{tabular}

\section{Campus Average Student Characteristics}

$\begin{array}{lccccc}\text { Test Score } & -0.036 & -0.037 & -0.041 & -0.031 & -0.051 \\ & {[-3.58]} & {[-3.27]} & {[-4.01]} & {[-3.95]} & {[-2.31]} \\ \begin{array}{l}\text { \% eligible for } \\ \text { subsidized lunch }\end{array} & 0.00 & -0.03 & 0.00 & 0.04 & 0.01 \\ & {[0.09]} & {[-1.09]} & {[0.16]} & {[1.24]} & {[0.15]} \\ \text { \% Black } & 0.13 & 0.09 & 0.03 & 0.01 & -0.09 \\ & {[4.75]} & {[3.30]} & {[0.98]} & {[0.52]} & {[-1.54]} \\ & & & & & \\ \text { \% Hispanic } & 0.03 & 0.05 & -0.01 & -0.03 & -0.09 \\ & {[1.01]} & {[1.36]} & {[-0.22]} & {[-0.67]} & {[-1.27]}\end{array}$

Interactions with Race/ethnicity of Teacher

\begin{tabular}{lllllc} 
Black * & -0.26 & -0.17 & -0.10 & -0.08 & 0.08 \\
\% Black & {$[-8.24]$} & {$[-4.68]$} & {$[-2.92]$} & {$[-3.68]$} & {$[1.29]$} \\
& & & & & \\
$\begin{array}{l}\text { Black* } \\
\text { \% Hispanic }\end{array}$ & -0.14 & -0.04 & -0.05 & -0.06 & 0.10 \\
& {$[-3.68]$} & {$[-0.88]$} & {$[-1.88]$} & {$[-4.08]$} & {$[1.46]$} \\
$\begin{array}{l}\text { Hispanic } * \\
\text { \% Black }\end{array}$ & -0.15 & -0.04 & -0.05 & -0.06 & 0.10 \\
& {$[-3.40]$} & {$[-0.86]$} & {$[-0.77]$} & {$[-2.21]$} & {$[1.96]$} \\
$\begin{array}{l}\text { Hispanic * } \\
\text { \% Hispanic }\end{array}$ & -0.12 & -0.09 & -0.07 & -0.07 & 0.07 \\
\hline observations & {$[-3.82]$} & {$[-2.79]$} & {$[-2.72]$} & {$[-2.92]$} & {$[0.68]$} \\
\hline
\end{tabular}


specification, raising doubt about the frequently hypothesized impact of smaller classes on teacher decisions. $^{22}$

To consider unobserved district factors, we re-estimate the models with district fixed-effects that remove the influence of any time invariant district factors. Table 8 shows that the magnitudes of the coefficients on percent Black and percent Hispanic actually increase, suggesting that teachers respond more strongly to changes in student demographics. The inclusion of fixed effects also raises the magnitude and significance of the coefficient on eligibility for a subsidized lunch, but the direction of the effect is inconsistent with a labor supply story in which teachers prefer districts with higher income children. More likely, the negative relationship for subsidized lunch reflects institutional changes at schools related to Texas school finance reform efforts. Schools with less wealthy student populations experienced revenue increases during this period, money which may have been used to make teaching more attractive (in ways not measured here).

In contrast to the other variables and the findings of Murnane et al (1996), the significant salary coefficients disappear once district fixed effects are included. It could be that the true impact of salaries is quite small. Alternatively, there could be insufficient salary variations across time, or the effects of hiring and retention policies could cancel out the labor supply response to higher salaries. For example, districts that raise salaries may also introduce more rigorous hiring and retention criteria, or they may experience an unobserved worsening of working conditions. Overall, the pattern of salary changes

\footnotetext{
${ }^{22}$ Multinomial logit estimates (shown in Appendix Table A1) indicate that teacher salary is much more strongly related to the probability of switching districts (relative to remaining) than to the probability of exiting the Texas public schools. The pattern of transitions related to the percent of students who are Black, including the interactions with teacher race/ethnicity, are similar to those of the earlier tables, while the percent eligible for a subsidized lunch is positively related to the probability of switching districts.
} 
Table 8. Effects of District Base Salary and Student Characteristics on Probability of Leaving Current Campus, by Teacher Experience (Linear probability models with district fixed effects, tstatistics in parentheses)

$$
\text { teacher experience }
$$

0-2 yrs $\quad 3-5 \mathrm{yrs} \quad 6-10 \mathrm{yrs} \quad 11-30 \mathrm{yrs} \quad>30$ years

$\begin{array}{lccccc}\log \text { base year } & 0.06 & -0.03 & -0.06 & 0.00 & 0.35 \\ \text { salary } & {[0.73]} & {[-0.22]} & {[-0.44]} & {[0.04]} & {[0.60]}\end{array}$

Campus Average Student Characteristics

$\begin{array}{lccccc}\text { Test Score } & -0.030 & -0.029 & -0.036 & -0.026 & -0.056 \\ & {[-2.56]} & {[-2.72]} & {[-3.09]} & {[-2.88]} & {[-2.48]} \\ \text { \% eligible for } & -0.06 & -0.07 & -0.05 & 0.00 & -0.05 \\ \text { subsidized lunch } & {[-2.59]} & {[-2.87]} & {[-1.95]} & {[-0.20]} & {[-0.60]} \\ \text { \% Black } & 0.20 & 0.16 & 0.12 & 0.06 & -0.09 \\ & {[7.68]} & {[5.74]} & {[5.12]} & {[4.15]} & {[-1.05]} \\ & & & & & \\ \text { \% Hispanic } & 0.10 & 0.12 & 0.09 & 0.04 & -0.05 \\ & {[3.44]} & {[3.55]} & {[3.32]} & {[1.72]} & {[-0.51]}\end{array}$

Interactions with Race/ethnicity of Teacher

$\begin{array}{llcccc}\text { Black * } & -0.26 & -0.18 & -0.10 & -0.06 & 0.12 \\ \text { \% Black } & {[-7.86]} & {[-4.95]} & {[-3.34]} & {[-3.24]} & {[1.68]} \\ & & & & & \\ \text { Black * } & -0.14 & -0.03 & -0.06 & -0.05 & -0.09 \\ \text { \% Hispanic } & {[-3.64]} & {[-0.74]} & {[-2.21]} & {[-4.50]} & {[1.12]} \\ & & & & & \\ \text { Hispanic * } & -0.16 & -0.07 & -0.09 & -0.07 & 0.28 \\ \text { \% Black } & {[-3.79]} & {[-1.52]} & {[-1.50]} & {[-2.27]} & {[1.25]} \\ & & & & & -0.02 \\ \text { Hispanic * } & -0.12 & -0.08 & -0.07 & -0.07 & {[-0.15]} \\ \text { \% Hispanic } & {[-4.51]} & {[-2.88]} & {[-2.90]} & {[-4.28]} & \\ & & & & & 5,474\end{array}$


suggests that salaries affect choices, though it is not possible to identify the precise size of the labor supply response.

\section{Teacher Salaries, Mobility and Student Achievement}

From a policy point of view, the most important question remains: Given district hiring practices, would an increase in salaries raise achievement?

Salaries may affect teacher quality in a number of ways. First, an increase in salaries likely enlarges the pool of applicants, but, even an expansion that raises average quality does not guarantee a positive relationship between teacher quality and salaries. The resulting change in quality depends crucially on both the hiring practices of districts and the decisions of teachers about retirement and exiting. Second, higher salaries might raise achievement by raising the effort of current teachers. For example, salary negotiations may explicitly link higher salaries with an expansion of responsibilities, or teachers may simply work harder in order to raise the likelihood of retaining their now more desirable job (in an efficiency wage sense). In the latter case, one would expect untenured teachers to have the strongest response in terms of effort. Tenure is not as prevalent or as strong in Texas as in other states, and there is substantial variation across districts in the degree of job security. However, teachers with less than three

years of experience unambiguously enjoy the least amount of job security, and any effects on effort should be strongest on this group.

Two approaches used to estimate the link between teacher quality and pay are presented in turn. First, we consider the effects of starting salary on explicit measures of quality, the district average certification test scores for new teachers. Second, we examine the direct effects of salary on student achievement, controlling for student and other school characteristics. 


\section{Teacher test scores and pay}

Estimates of the relationship between two teacher certification test scores and district starting salaries rely on the sample of new teachers in the years 1993 to $1996 .{ }^{23}$ These scores come from the two main elementary school components of the Examination for the Certification of Educators in Texas (EXCET). Both the Professional Development and Comprehensive tests are administered to the majority of new entrants into Texas elementary schools. Roughly two-thirds have valid scores for both examinations. ${ }^{24}$ Both tests concentrate on knowledge of pedagogy (while subject matter tests are administered primarily to secondary school teachers). We have transformed the reported scores into percentile scores, though other transformations including z scores produce virtually identical results. Percentile scores have the advantage of reflecting directly the location that districts draw teachers from in the test score distribution.

Equation 3 describes the empirical model that forms the basis of our analysis,

$$
\text { AdjScore }_{d t}=\operatorname{Sal}_{d t} \beta+S_{d t} \lambda+R_{d} \alpha_{R}+C_{d} \alpha_{C}+Y_{t} \alpha_{Y}+\varepsilon_{d t}
$$

where AdjScore is a district test-year-adjusted average score on the professional development or comprehensive test ${ }^{25} \mathrm{Sal}_{\mathrm{dt}}$ is the level of starting salary for district $\mathrm{d}$ in year $\mathrm{t}$; $\mathrm{S}$ is a vector of district average student demographic characteristics including percent eligible for a free or reduced price lunch, percent Black, percent Hispanic, and student test score; R is a vector of 19 region dummies; C is a vector

\footnotetext{
${ }^{23}$ We thank the State Board of Educator Certification for providing us with the data on the teacher certification tests.

${ }^{24} \mathrm{~A}$ very small percentage (less than $.1 \%$ ) scored less than random and were dropped. We are investigating the reasons for missing scores, though the data suggest that the test files are missing information for specific districts in some years.

${ }^{25}$ The adjusted scores are generated as residuals from a first stage that simply removes year effects for the date the test was taken. Anecdotal evidence as well as descriptive statistics for raw test scores suggests that scores tend to rise the longer the specific test instrument is in use and fall at the time a new test is introduced. The residual scores are aggregated by district and year to produce district- specific average test scores for each year.
} 
of three community types (large city, small city and suburban); Y is a vector of three year dummies; $\beta, \lambda$, and the $\alpha$ 's are parameters to be estimated; and $\epsilon$ is a random error.

Table 9 presents eight specifications of the estimated effects of starting salary on the two test scores. The specifications differ along three dimensions: 1) whether student demographic characteristics are included; 2) whether district fixed effects are included; and 3) whether the regressions are weighted by the number of teachers in each district. The largest district is dropped because its inclusion dramatically altered the coefficients in the weighted regressions.

The results show little relationship between salary and either test score. None of the sixteen coefficients are statistically significant at any conventional level, and the same pattern (not shown) is produced if the percent who fail the test is used in place of average score. Perhaps the most striking aspect of Table 9 is the dramatic difference between weighted and unweighted results. Specifications that weight observations on the basis of the number of new teachers with valid tests in a district tend at least to produce positive point estimates, although none are statistically different from zero.

The different patterns for weighted and unweighted estimates suggest that the link between test score and salary differs by district size. This conjecture is confirmed by Table 10, which reports estimated effects of teacher salary by district size. Average teacher test scores are positively related to starting salaries only in districts that hire at least seven new teachers (the top quartile on the basis of new teachers hired), and the relationship is quite significant for the professional development test. The coefficient magnitude of 46.1 suggests that a ten percent increase in starting salary increases district average test score by 5 percentiles. It should be noted that the professional development test appears to be far more difficult than the comprehensive test, as the failure rate is almost three times as high. 
Table 9. Estimated effects of starting salary on the quality of first year teachers as measured by the district average score on the Professional Development Test and the Elementary School Comprehensive Test ( $\mathrm{t}$-statistics in parentheses)

\section{Weighted}

$\begin{array}{lcccr}\text { Professional Development } & 0.08 & 4.80 & 14.00 & 13.00 \\ & (0.02) & (1.23) & (1.44) & 1.34) \\ \text { Comprehensive } & -0.57 & 3.88 & 1.67 & 1.14 \\ & (-0.16) & (1.04) & (0.19) & (0.13)\end{array}$

\section{Not Weighted}

Professional Development

$-5.80$

$-4.77$

$-23.20$

$-24.00$

$(-0.99)$

$(-0.78)$

$(-1.49)$

$(-1.55)$

Comprehensive

$\begin{array}{ll}-4.99 & -4.39 \\ (-0.91) & (-0.77)\end{array}$

$-22.50$

$-23.10$

district fixed effects
student demographics

$(-0.91)$

(-0.77)

$\begin{array}{ll}\text { no } & \text { no } \\ \text { no } & \text { yes }\end{array}$

yes

yes

no

yes

Note: Estimates are based on 2,336 observations for the Professional Development test and 2,373 observations for the Comprehensive test. 
Table 10. Estimated effects of starting salary on the quality of first year teachers as measured by the district average score on the Professional Development Test and the Elementary School Comprehensive Test, by quartile of district number of teachers hired (unweighted estimates with district fixed effects and student demographics; $t$-statistics in parentheses)

\begin{tabular}{lcccc} 
& \multicolumn{4}{c}{ Number of first year teachers hired } \\
\cline { 2 - 5 } Professional Development & 1 & $2-3$ & $4-6$ & $>7$ \\
\cline { 2 - 5 } & -90.5 & -28.4 & -27.7 & 46.1 \\
Comprehensive & $(-1.16)$ & $(-0.74)$ & $(-0.48)$ & $(3.34)$ \\
& -70.2 & -6.6 & -16.9 & 15.9 \\
& $(-0.95)$ & $(-0.18)$ & $(-0.37)$ & $(1.22)$
\end{tabular}

Observations

Professional Development

525

780

372

679

Comprehensive

525

786

371

695

One interpretation of these results is that larger districts make better use of the enlarged applicant

pool generated by higher salaries. The interpretation is clouded, however, because preliminary regressions show no evidence that these Excet scores are positively related to mathematics

or reading achievement for students in the Texas public schools. ${ }^{26}$ Large districts appear to use more objective criteria in their hiring practices despite the fact that these tests do not seem to be very informative about quality. In any event, the fact that other districts do not exhibit a preference for higher scores does

\footnotetext{
${ }^{26}$ This preliminary work did not, for example, explore the possibility that test scores have different meanings for Black and White teachers, as suggested by Murnane et al. (1991). Future work will consider such possibilities. Ferguson(1991) found that district aggregate TECAT scores were positively related to district average student achievement in Texas during the late 1980s. TECAT tested subject matter knowledge, while EXCET tests mainly pedagogy. It may be possible in this analysis to explore different subsets of EXCET data to obtain measures more content related.
} 
not imply bad hiring practices; rather it could simply be the appropriate response to information that is not strongly related to true quality.

\section{Student Achievement and Pay}

The weak relationship between the teacher tests and student achievement gains reaffirms the difficulty of measuring quality on the basis of an observable teacher characteristic. Our preferred alternative concentrates directly on student performance measures. We use the matched panels of students and teachers to investigate the impact of teacher salaries on mathematics and reading achievement in 4th and 5th grade. ${ }^{27}$ An important element is disentangling any effects on achievement of teacher turnover per se from effects that work through changes in the quality of new teachers or in effort. Equation 4 describes the empirical model that forms the basis of our analysis,

$$
\Delta A_{i g s t}=S a l_{d t} \beta+S_{g s t} \lambda+X_{i} \delta+\gamma_{i}+\varepsilon_{i g s t}
$$

where $\Delta \mathrm{A}_{\text {igst }}$ is the change in achievement ${ }^{28}$ for student $\mathrm{i}$ in grade $\mathrm{g}$ in school $\mathrm{s}$ in year $\mathrm{t}$; Sal is the empirical measure of median district salary for teachers of a specific experience and education category; $\mathrm{S}$ is a vector of school and teacher characteristics; $\mathrm{X}$ is a vector of individual and family background characteristics; $\mathrm{C}$ is a vector of community type and region dummy variables; and $\beta, \lambda$, $\delta$, and $\eta$ are achievement parameters. The error includes constant individual specific factors, $\gamma_{\mathrm{i}}$, plus a time varying component, $\epsilon_{\mathrm{igst}}$. The family

\footnotetext{
${ }^{27}$ All students and teachers who participate in special or bilingual education are dropped from the analysis.

${ }^{28}$ Change in achievement in grade $\mathrm{g}$ is calculated as the difference between the test score in the spring of grade $g$ and the test score in the spring of grade g- 1 . The underlying value-added model conditions current achievement on a prior measure of achievement and on intervening inputs. This formulation, which we apply in a simple difference form for standardized achievement scores in equation (4), eliminates any fixed individual differences in the level of achievement, effectively accounting for the entire history of school and family inputs that affect the level of achievement in grade $t-1$. It also handles variations in ability to the extent that they affect levels of performance. It does not, however, deal with any unmeasured conditions that might affect the rate of learning gain.
} 
characteristics include information on race, ethnicity, gender, and eligibility for free or reduced price lunches. Teacher and school characteristics other than salary are computed separately for each grade and subject, and they include the average class size for regular students, the percentage of teachers grouped into seven experience categories, the percentage of teachers in five transition categories determined by status in the previous year, ${ }^{29}$ and three measures of student demographic composition (percentage Black, percentage Hispanic, and percentage eligible for a subsidized lunch). The analysis focuses on the effects of the level of a district's salary schedule, as measured by the log of starting teacher salary. Individual teacher movements along the district's salary schedule are separately analyzed through inclusion of teacher experience and teacher graduate training, the primary determinants of position within the district's salary structure. Descriptive characteristics are reported in Appendix Table A2.

In the case of teacher salaries, communities that opt for higher pay scales may have other unobserved attributes that are positively related to achievement. For example, higher paying communities may have better computer facilities, better school administrators, better public services outside of education, or a community environment more conducive to learning. Each of these factors could introduce a positive bias to the estimate of teacher salary effects on achievement. On the other hand, communities with higher pay scales may have other, unobserved characteristics that tend to reduce teacher quality.

Differences in housing or transportation costs, alternative job opportunities, and poorer working conditions are three types of factors that could introduce a negative bias on the estimate of teacher salary effects. We include twenty region dummies, three community type dummies, and the various school characteristics to account for the influence of such other factors on teacher labor markets, although it remains possible that important factors might not be captured by these variables.

\footnotetext{
${ }^{29}$ Included categories are: same campus but different grade, new campus but same district, different district and not in Texas public schools (with same campus and grade as the omitted category).
} 
Fortunately, the repeated test scores available in the Texas data offer promise for correcting problems of omitted variables bias by including individual fixed effects into equation (4) ${ }^{30}$ The individual fixed effect estimator can be written as deviations (symbolized by the dot) from each student's mean of all variables, as in Equation (5). In this formulation, all time invariant individual, family, and community factors that might contaminate the estimates of teacher salary effects are eliminated.

(5) $\Delta A_{\text {igst. }}=\operatorname{Sal}_{d t .} \beta+S_{\text {gst. }} \lambda+\varepsilon_{\text {igst. }}$

In addition, restricting the samples to students who remain in the same schools for the fourth and fifth grades eliminates the possibility that changes in school quality that accompany a student's change of school contaminate the teacher salary coefficients. ${ }^{31}$

The advantages of student fixed effects come at a cost, because all cross-sectional variation in salary is eliminated and the effects of salary are identified from changes over time in individual district salary levels. If year-to-year starting salary changes are not reflective of changes in expected career earnings either because of noise, differences in salary growth across experience categories, or other factors, the fixed effect estimates may be downwardly biased by measurement error. It is also possible that salary changes are correlated with other changes in or local labor markets schools that affect achievement. In this case the direction of the bias is not known a priori. We use a number of specification tests to examine the importance of these potential problems.

${ }^{30}$ District fixed effects are an alternative to fully controlling for unobserved student and school factors. Preliminary work showed that the pattern of district fixed effect estimates is quite similar to that of student fixed effects.

${ }^{31}$ This sample restriction accounts for school fixed effects in a computationally tractable way without having to add school dummy variables to the specifications. Because individual fixed effects are removed, the results should generalize to all students. 
Table 11. Effects of District Base Salary and Teacher Characteristics on $4^{\text {th }}$ and $5^{\text {th }}$ Grade Achievement Gains (Huber-White adjusted t-statistics in parentheses)

4th Grade

5th Grade

4th and 5th Grade

\begin{tabular}{|c|c|c|c|c|c|c|c|c|c|}
\hline \multirow{2}{*}{\multicolumn{10}{|c|}{ 4th and 5th Grade }} \\
\hline & & & & & & & & & \\
\hline base year salary & $\begin{array}{r}-0.18 \\
{[-2.07]}\end{array}$ & $\begin{array}{l}-0.19 \\
{[-2.15]}\end{array}$ & $\begin{array}{l}-.0 .20 \\
{[-2.35]}\end{array}$ & $\begin{array}{l}-0.03 \\
{[-0.44]}\end{array}$ & $\begin{array}{l}-0.04 \\
{[-0.58]}\end{array}$ & $\begin{array}{l}-0.04 \\
{[-0.65]}\end{array}$ & $\begin{array}{c}0.68 \\
{[2.17]}\end{array}$ & $\begin{array}{l}0.66 \\
{[2.09]}\end{array}$ & $\begin{array}{c}0.62 \\
{[1.96]}\end{array}$ \\
\hline$\% 0 \mathrm{yr}$ experience & & $\begin{array}{l}-0.08 \\
{[-2.15]}\end{array}$ & $\begin{array}{c}0.00 \\
{[-0.08]}\end{array}$ & & $\begin{array}{l}-0.11 \\
{[-5.13]}\end{array}$ & $\begin{array}{l}-0.11 \\
{[-4.33]}\end{array}$ & & $\begin{array}{l}-0.02 \\
{[-0.32]}\end{array}$ & $\begin{array}{c}0.04 \\
{[0.59]}\end{array}$ \\
\hline$\% 1 \mathrm{yr}$ experience & & $\begin{array}{l}0.01 \\
{[0.19]}\end{array}$ & $\begin{array}{c}0.02 \\
{[0.62]}\end{array}$ & & $\begin{array}{l}-0.05 \\
{[-2.14]}\end{array}$ & $\begin{array}{l}-0.05 \\
{[-2.12]}\end{array}$ & & $\begin{array}{l}0.02 \\
{[0.46]}\end{array}$ & $\begin{array}{c}0.03 \\
{[0.55]}\end{array}$ \\
\hline $\begin{array}{l}\% \text { in another district } \\
\text { previous year }\end{array}$ & & & $\begin{array}{l}-0.06 \\
{[-1.06]}\end{array}$ & & & $\begin{array}{l}0.03 \\
{[0.97]}\end{array}$ & & & $\begin{array}{c}0.02 \\
{[0.26]}\end{array}$ \\
\hline $\begin{array}{l}\% \text { did not teach } \\
\text { previous year }\end{array}$ & & & $\begin{array}{l}-0.11 \\
{[-2.82]}\end{array}$ & & & $\begin{array}{c}0.00 \\
{[-0.25]}\end{array}$ & & & $\begin{array}{l}-0.08 \\
{[-1.57]}\end{array}$ \\
\hline \multicolumn{10}{|l|}{ Reading } \\
\hline base year salary & $\begin{array}{c}0.07 \\
{[1.03]}\end{array}$ & $\begin{array}{l}0.06 \\
{[0.90]}\end{array}$ & $\begin{array}{l}0.05 \\
{[0.85]}\end{array}$ & $\begin{array}{l}0.00 \\
{[0.12]}\end{array}$ & $\begin{array}{c}0.00 \\
{[0.09]}\end{array}$ & $\begin{array}{c}0.00 \\
{[-0.09]}\end{array}$ & $\begin{array}{l}0.79 \\
{[3.23]}\end{array}$ & $\begin{array}{l}0.79 \\
{[3.24]}\end{array}$ & $\begin{array}{c}0.80 \\
{[3.22]}\end{array}$ \\
\hline$\% 0 \mathrm{yr}$ experience & & $\begin{array}{l}-0.08 \\
{[-2.15]}\end{array}$ & $\begin{array}{c}0.00 \\
{[-0.08]}\end{array}$ & & $\begin{array}{l}-0.04 \\
{[-2.96]}\end{array}$ & $\begin{array}{l}-0.04 \\
{[-1.96]}\end{array}$ & & $\begin{array}{c}0.00 \\
{[-0.02]}\end{array}$ & $\begin{array}{c}0.02 \\
{[0.45]}\end{array}$ \\
\hline$\% 1$ year experience & & $\begin{array}{l}0.01 \\
{[0.19]}\end{array}$ & $\begin{array}{c}0.02 \\
{[0.62]}\end{array}$ & & $\begin{array}{l}-0.03 \\
{[-1.66]}\end{array}$ & $\begin{array}{l}-0.02 \\
{[-1.52]}\end{array}$ & & $\begin{array}{l}0.00 \\
{[0.00]}\end{array}$ & $\begin{array}{c}0.00 \\
{[-0.03]}\end{array}$ \\
\hline $\begin{array}{l}\% \text { in another dist. } \\
\text { previous year } \\
\% \text { did not teach previous } \\
\text { year }\end{array}$ & & & $\begin{array}{l}-0.06 \\
{[-1.06]} \\
-0.11 \\
{[-2.82]}\end{array}$ & & & $\begin{array}{l}-0.01 \\
{[-0.60]} \\
-0.02 \\
{[-1.28]}\end{array}$ & & & $\begin{array}{l}0.07 \\
{[1.50]} \\
-0.02 \\
{[-0.62]}\end{array}$ \\
\hline $\begin{array}{l}\text { student fixed effects } \\
\text { school nonmovers }\end{array}$ & $\begin{array}{l}\text { no } \\
\text { no }\end{array}$ & $\begin{array}{l}\text { no } \\
\text { no }\end{array}$ & $\begin{array}{l}\text { no } \\
\text { no }\end{array}$ & $\begin{array}{l}\text { no } \\
\text { no }\end{array}$ & $\begin{array}{l}\text { no } \\
\text { no }\end{array}$ & $\begin{array}{l}\text { no } \\
\text { no }\end{array}$ & $\begin{array}{l}\text { yes } \\
\text { yes }\end{array}$ & $\begin{array}{l}\text { yes } \\
\text { yes }\end{array}$ & $\begin{array}{l}\text { yes } \\
\text { yes }\end{array}$ \\
\hline $\begin{array}{l}\text { observations - math } \\
\text { observations - reading }\end{array}$ & & $\begin{array}{l}156,924 \\
156,391\end{array}$ & & & $\begin{array}{l}472,142 \\
470,846\end{array}$ & & & $\begin{array}{l}92,526 \\
92,452\end{array}$ & \\
\hline
\end{tabular}

Results of Achievement Estimation 
Table 11 reports the estimated effects of teacher salary on 4th and 5th grade math and reading achievement. The basic OLS estimates for 4th and 5th grade show little or no evidence that teacher salary has a significant effect on achievement. Regardless of whether controls for experience and turnover are included in the specification, none of the salary coefficients is positive and statistically significant at any conventional level.

The inclusion of student fixed effects in the final three columns, however, produces a dramatic change in the estimated effect of salaries. All fixed effect salary coefficients are positive and significant, and the results are remarkably similar for both reading and math. In both cases there is little evidence that reducing turnover is an important mechanism through which salaries improve performance. The reading coefficient is invariant to the presence of controls for experience and turnover while the inclusion of these controls decreases the math coefficient by less than 10 percent. Therefore the fixed effect estimates suggest that salaries work either by raising the quality of recent hires or by encouraging current teachers to improve their performance.

Because of the problems of using short panels of data in this context, however, we undertake a series of specification tests in order to learn more about the causal link that underlies the observed association between changes in achievement and changes in starting salaries. First, year-to-year changes in starting salaries are likely to be noisy measures of changes over time in a district's salary structure. Viewed from a measurement error perspective, this could attenuate the estimates of the contribution of salary differences to achievement. To address this possibility, we use second year salaries as an instrument for first year salaries. This IV approach should reduce any bias caused by misreporting and by changes in starting salaries that are uncorrelated with changes at other points of the experience distribution. ${ }^{32}$

\footnotetext{
${ }^{32}$ Preliminary work showed similar fixed effect estimates using 5th year salaries in place of starting salaries.
} 
Table 12. IV Estimated Effects of Starting Teacher Salary on 4th and 5th Grade Math and Reading Test Score Gains (no controls for experience or turnover, Huber-White adjusted t-statistics in parentheses)

\begin{tabular}{lccc} 
& 4th Grade & 5th Grade & $\begin{array}{c}\text { 4th and 5th } \\
\text { Grade }\end{array}$ \\
\hline Math & -0.21 & 0 & 1.71 \\
& {$[-2.02]$} & {$[0.07]$} & {$[4.26]$} \\
Reading & -0.01 & -0.01 & 1.11 \\
& {$[-0.18]$} & {$[-0.26]$} & {$[3.54]$} \\
& & & \\
student fixed effects & no & no & yes \\
school nonmovers & no & no & yes
\end{tabular}

Note: District salary for second year teachers is used as an instrument for salary of first year teachers. Estimates based on 88,372 students for math and 88,287 for reading.

The IV results in Table 12 provide evidence consistent with the notion that changes in starting salaries are a noisy measure of changes in the overall salary structure. The math coefficient in the fixed effect model increases by a factor of 2.5 , while the reading coefficient increases by roughly 50 percent. The coefficients imply that a 10 percent increase in starting salaries would raise math achievement by .17 standard deviations and reading achievement by .11 standard deviations. These magnitudes are somewhat larger than the estimated class size effects (per dollar of expenditure) obtained with the same data (Rivkin, Hanushek and Kain 1998).

The IV results strengthen the finding that changes in achievement are positively related to changes in salaries, but the question remains whether this relationship captures a causal effect. Evidence that the reduction of teacher turnover makes little or no contribution to the link between salaries and achievement raises some doubts about the underpinnings of the salary/achievement relationship, because it is the reduction of turnover that is thought to be the most likely path through which high salaries improve teacher quality. 
We performed a series of specification checks in order to test the robustness of the results. First, we examined a number of possible confounding factors by including measures of the percentage of children classified in special education ${ }^{33}$, enrollment, and indicator variables for new superintendents and new principals. These additional factors, while often statistically significant, had little effect on the salary coefficients. We also used measures of state aid to the district (both current and lagged) as instrumental variables in an effort to identify the link between salaries and teacher quality through changes in revenue that were unrelated to changes in student composition within districts. Unfortunately, the first stage explanatory power was very low, and these IV estimates proved to be uninformative.

More telling, we divided the sample up by the percentage of teachers who were not in the district in the previous year and the percentage of probationary status teachers ( $0-2$ years experience). If salaries were increasing achievement primarily by improving the quality of new hires, the relationship between achievement and salaries should be strongest in schools that recently hired new teachers. Similarly, if salaries were increasing achievement primarily by providing incentives for improved teaching, it should be the case that the relationship between achievement and salaries is strongest in schools with a higher percentage of probationary teachers.

The results in the top panel of Table 13, remarkably similar for math and reading, are inconsistent with both hypotheses. The largest and most significant salary effects are found in the sample of schools with no turnover and with no probationary teachers. This pattern and the magnitude of the estimates are

\footnotetext{
${ }^{33}$ Hanushek, Kain and Rivkin (1998) find that achievement for non-special education students is positively related to the special education classification rate. While the precise mechanism for this effect is unclear, the positive interaction result is robust to a variety of specifications and estimation approaches.
} 
Table 13. IV Estimated Effects of District Salary on $4^{\text {th }}$ and $5^{\text {th }}$ Grade Math and Reading Achievement, by Presence of Probationary Teachers and Existence of Teacher Turnover and by Controls for Region by Year Interactions (no controls for experience or turnover, Huber-White adjusted t-statistics in parentheses)

\begin{tabular}{|c|c|c|c|c|c|c|c|}
\hline & \multirow[t]{2}{*}{ All } & \multicolumn{3}{|c|}{$\begin{array}{l}\text { years with at least one } \\
\text { probationary teacher }\end{array}$} & \multicolumn{3}{|c|}{$\begin{array}{l}\text { years with teacher } \\
\text { turnover }\end{array}$} \\
\hline & & 0 & 1 & 2 & 0 & 1 & 2 \\
\hline \multicolumn{8}{|c|}{ 1. No Region/Year Interactions } \\
\hline Math & $\begin{array}{c}1.71 \\
{[4.26]}\end{array}$ & $\begin{array}{c}2.44 \\
{[4.87]}\end{array}$ & $\begin{array}{c}0.50 \\
{[0.48]}\end{array}$ & $\begin{array}{c}0.82 \\
{[1.02]}\end{array}$ & $\begin{array}{c}2.26 \\
{[3.53]}\end{array}$ & $\begin{array}{l}1.64 \\
{[2.49]}\end{array}$ & $\begin{array}{l}1.11 \\
{[1.34]}\end{array}$ \\
\hline Reading & $\begin{array}{c}1.11 \\
{[3.54]}\end{array}$ & $\begin{array}{l}1.29 \\
{[2.99]}\end{array}$ & $\begin{array}{l}0.48 \\
{[0.67]}\end{array}$ & $\begin{array}{l}1.12 \\
{[1.95]}\end{array}$ & $\begin{array}{l}1.60 \\
{[3.23]}\end{array}$ & $\begin{array}{l}1.10 \\
{[2.10]}\end{array}$ & $\begin{array}{l}0.76 \\
{[1.24]}\end{array}$ \\
\hline \multicolumn{8}{|c|}{ 2. Includes Region/Year Interactions } \\
\hline Math & $\begin{array}{c}1.24 \\
{[2.39]}\end{array}$ & $\begin{array}{l}1.73 \\
{[2.56]}\end{array}$ & $\begin{array}{l}1.73 \\
{[1.44]}\end{array}$ & $\begin{array}{c}-0.16 \\
{[-0.16]}\end{array}$ & $\begin{array}{c}2.30 \\
{[3.33]}\end{array}$ & $\begin{array}{c}0.87 \\
{[0.96]}\end{array}$ & $\begin{array}{c}0.73 \\
{[0.70]}\end{array}$ \\
\hline Reading & $\begin{array}{c}0.76 \\
{[1.91]}\end{array}$ & $\begin{array}{l}0.75 \\
{[1.33]}\end{array}$ & $\begin{array}{l}1.14 \\
{[1.35]}\end{array}$ & $\begin{array}{l}0.80 \\
{[1.13]}\end{array}$ & $\begin{array}{l}1.57 \\
{[2.55]}\end{array}$ & $\begin{array}{l}0.73 \\
{[1.08]}\end{array}$ & $\begin{array}{c}0.04 \\
{[0.05]}\end{array}$ \\
\hline \multirow{2}{*}{\multicolumn{2}{|c|}{$\begin{array}{l}\text { Individual fixed effects } \\
\text { School nonmovers }\end{array}$}} & yes & yes & yes & yes & yes & yes \\
\hline & & yes & yes & yes & yes & yes & yes \\
\hline \multicolumn{8}{|c|}{$\overline{\text { Observations }}$} \\
\hline $\begin{array}{l}\text { Math } \\
\text { Reading }\end{array}$ & & $\begin{array}{l}44,492 \\
42,767\end{array}$ & $\begin{array}{l}15,130 \\
14,687\end{array}$ & $\begin{array}{l}28,750 \\
30,833\end{array}$ & $\begin{array}{l}26,807 \\
26,848\end{array}$ & $\begin{array}{l}35,693 \\
35,608\end{array}$ & $\begin{array}{l}25,872 \\
25,831\end{array}$ \\
\hline
\end{tabular}

virtually unchanged by the inclusion of measures of experience and turnover in the regressions, implying they are not driven by differences in turnover rates. The results are also very similar if starting salaries are not instrumented by $2^{\text {nd }}$ year salaries. Overall, these estimates suggest that if teacher salary raises achievement, it does so primarily by causing existing teachers to improve their performance following a salary increase. The explanations that are consistent with the estimates are very different than those that normally dominate 
discussions of teacher salary effects, even by teacher organizations. Moreover, the finding that year-to-year changes in salaries had no significant effect on teacher transitions for any experience category suggested that the signal contained in such changes might be overwhelmed by the noise, but only the fixed effect achievement specifications that are identified by year-to-year changes produce a strong pattern of salary effects.

An alternative explanation for the results in Table 13 is that the observed relationship between achievement and salaries confounds any salary effect with the influence of unobserved factors that also affect achievement. In order to examine one aspect of this possibility, region-by-year interactions are included in the fixed effects specifications. These dummy variables capture any systematic differences across regions in the change in test score gains. The inclusion of region dummies substantially reduces the magnitude of the salary coefficients, though the above pattern of estimates is largely preserved. The salary coefficient for all schools falls from 1.71 to 1.24 for the math specifications and from 1.11 to 0.76 for the reading specifications, roughly a 30 percent decline in both. In contrast, the class size estimate (not shown) remains virtually unchanged by the inclusion of the region dummies. Moreover, the inclusion of the region dummies reduces dramatically the estimated effects for the sample of schools with two years of probationary teachers or two years in which there is turnover.

The sensitivity of the salary coefficients to the region dummies suggests that omitted variables bias may be a serious problem with these panel data estimates of teacher salary effects on achievement. It is likely that other determinants of achievement that vary within rather than merely between regions may also be correlated with changes in the structure of salaries and that the observed relationship between achievement and salaries does not capture a strong causal link between salaries and the quality of teachers in a district. 


\section{Conclusions}

There is no question that teachers exert a tremendous impact on academic performance, but the question of how to ensure high quality teaching remains largely unanswered. Our previous analysis of achievement (Rivkin, Hanushek, and Kain 1998) indicated that teacher quality explained a substantial portion of the variation in student achievement. However, it also showed that observable teacher characteristics including education and experience explained little of the variation in teacher quality. More importantly, that analysis provides strong evidence that most if not virtually all of the variation in teacher quality occurred within schools (and thus within school districts), suggesting that school and district-wide factors such as compensation could play a minor role at most.

Nevertheless, the question of whether schools effectively buy better teachers is an important question for education policy. It is also a difficult question to answer. Interpreting the observed reactions of teachers to variations in salaries is complicated, because the outcomes combine the influences of teacher supply, teacher demand, and teacher hiring and retention policies of districts. Moreover, because of variations in the attractiveness of different teaching jobs and the complexity of the relationship between current and past salaries and the current composition of teachers, contemporaneous salaries are unlikely to capture fully variations across districts in their attractiveness. Finally, it is very difficult to measure teacher quality directly. For all of these reasons, we used a number of different approaches to gain a greater understanding of the link between pay, teacher quality and student performance.

The first component of this analysis looks at mobility across schools and districts and at exiting from Texas public schools. Though it is not possible to identify structural supply elasticities, the evidence strongly suggests that teachers prefer certain types of students over others. Except for Black teachers, the typical Texas teacher appears to favor higher achieving, nonminority students. Black teachers on the other hand, while favoring higher achievement students, systematically move toward schools with higher concentrations of Black 
students. Net salaries adjusted for compensating differentials also appear to influence mobility and exiting, but to a lesser extent than characteristics of students.

The second empirical component investigates how shifts in the teacher salary scale are related to teacher quality and student achievement. Evidence from the analysis of teacher test scores suggests that larger districts make use of teacher certification test results in hiring teachers. While perhaps not a surprise that larger districts would tend to use more objective criteria such as test scores, the evidence suggests that these particular tests are not strongly related to student achievement. Thus we preliminarily conclude that their expanded use in the hiring process is unlikely to improve the quality of the teaching staff.

The second portion of the analysis of teacher quality examined the relationship between student test scores and district salaries. Estimation of typical value-added models of student math and reading performance for cohorts of $4^{\text {th }}$ and $5^{\text {th }}$ grade students yield no consistent relationships with district salaries. On the other hand, when student fixed effects are included in models of achievement growth and the sample is restricted to students who did not switch schools, salaries appear to have a significant positive effect on both math and reading test scores.

These results would appear to suggest that the included covariates in the achievement models do not capture fully all factors that contribute to compensating differentials, suppressing an underlying quality influence of salaries. However, specification checks raise doubts that the fixed effect estimates capture the true relationship between achievement and salaries. First, there is little evidence that higher salaries raise achievement by reducing turnover. Second, divisions of the sampled schools on the basis of teacher turnover and of teacher experience reveal that the strongest effects of salary are found in schools with no teacher turnover and no probationary teachers. Taken literally, this implies that salaries raise achievement primarily by increasing the work effort of experienced teachers, many of whom enjoy tenure protection, rather than by raising the quality of new hires, by retaining better teachers, or by raising the efforts of young teachers who lack job security. This pathway is not what typically underlies most salary discussions. Third, the inclusion 
of region dummies into the fixed effect specifications substantially reduced the magnitude of the salary coefficients, suggesting that the coefficients capture the influences of unobserved factors that change along with salaries.

The pattern of results is perplexing, but the overall analysis suggests that as currently employed, salary policies do not appear to offer much promise for improvement in student performance. Factors other than salaries appear to play a much more important role in determining the desirability of specific districts. More importantly, the earlier finding that the variation in teacher quality within schools appears to be much larger than any between school variation suggests that districts should focus on other ways to improve the quality of teaching and academic achievement.

\section{References}

Antos, Joseph R., and Sherwin Rosen. "Discrimination in the market for teachers." Journal of Econometrics 2 (May 1975): 123-50.

Ballou, Dale. "Do public schools hire the best applicants?" Quarterly Journal of Economics 111, no. 1 (February 1996): 97-133.

Ballou, Dale, and Michael Podgursky. "Recruiting smarter teachers." Journal of Human Resources 30, no. 2 (Spring 1995): 326-38.

---. Teacher pay and teacher quality. Kalamazoo, MI: W.E. Upjohn Institute for Employment Research, 1997.

Baugh, William H., and Joe A. Stone. "Mobility and wage equibration in the educator labor market." Economics of Education Review 2, no. 3 (Summer 1982): 253-74. N.

Betts, Julian R. "Is there a link between school inputs and earnings? Fresh scrutiny of an old literature." In Does money matter? The effect of school resources on student achievement and adult success, edited by Gary Burtless, 141-91. Washington, DC: Brookings, 1996.

Blais, André, and Stéphane Dion, eds. The budget-maximizing bureaucrat: Appraisals and evidence. Pittsburgh: University of Pittsburgh Press, 1991. 
Boardman, Anthony E., Linda Darling-Hammond, and Stephen P. Mullin. "A framework for the analysis of teachers' demand and supply." Economics of Education Review 2, no. 2 (Spring 1982): 127-55.

Boe, Erling E., and Dorothy M. Gilford, eds. Teacher supply, demand and quality. Washington, D.C.: National Academy Press, 1992.

Brewer, Dominic J. "Career paths and quit decisions: Evidence from teaching." Journal of Labor Economics 14, no. 2 (April 1996): 313-39.

Brown, Byron W., and Daniel H. Saks. "The production and distribution of cognitive skills within schools." Journal of Political Economy 83, no. 3 (June 1975): 571-93.

Card, David, and Alan B. Krueger. "Does school quality matter? Returns to education and the characteristics of public schools in the United States." Journal of Political Economy 100, no. 1 (February 1992): 1-40.

---. "School resources and student outcomes: An overview of the literature and new evidence from North and South Carolina." Journal of Economic Perspectives 10, no. 4 (Fall 1996): 31-50.

Carnegie Forum on Education and the Economy. A nation prepared: Teachers for the 21st century. : Carnegie Forum on Education and the Economy, 1986.

Chambers, Jay G. "The impact of collective bargaining for teachers on resource allocation in public school districts." Journal of Urban Economics 4, no. 3 (July 1977): 324-39.

Cohen, David K., and Richard J. Murnane. "Merit pay and the evaluation problem: Understanding why most merit pay plans fail and a few survive." Harvard Educational Review 56, no. 1 (February 1986): 1-17.

Darling-Hammond, Linda. Doing what matters most: Investing in quality teaching. New York: National Commission on Teaching and America's Future, 1997.

Dolton, Peter, and Wilbert van der Klaauw. "Leaving teaching in the UK: A duration analysis." The Economic Journal 105 (March 1995): 431-44.

---. "The turnover of teachers: A competing risks explanation." Review of Economics and Statistics (forthcoming).

Ferguson, Ronald. "Paying for public education: New evidence on how and why money matters." Harvard Journal on Legislation 28, no. 2 (Summer 1991): 465-98.

Ferguson, Ronald F. "Paying for Public Education: New Evidence on How and Why Money Matters." Harvard Journal on Legislation 28, no. 2 (Summer 1991): 465-98.

Flyer, Fredrick, and Sherwin Rosen. "The new economics of teachers and education." Journal of Labor Economics 15, no. 1 (part 2) (January 1997): 104-39.

Gilford, Dorothy M., and Ellen Tenenbaum, eds. Precollege science and mathematics teachers: monitoring supply, demand and quality. Washington, D.C.: National Academy Press, 1990. 
Goertz, Margaret E., Ruth B. Ekstrom, and Richard J. Coley. The impact of state policy on entrance into the teaching procession: Final report. : Educational Testing Service, 1984.

Greenberg, David, and John McCall. "Teacher mobility and allocation." Journal of Human Resources 9, no. 4 (Fall 1974): 480-502.

Grissmer, David W., and Sheila Nataraj Kirby. Patterns of attrition among indiana teachers, 1965-1987. Santa Monica: RAND, 1992.

Gritz, R. Mark, and Neil D. Theobald. "The effects of school district spending priorities on length of stay in teaching." Journal of Human Resources 31, no. 3 (Summer 1996): 477-512.

Grogger, Jeffrey T. "Does school quality explain the recent black/white wage trend?" Journal of Labor Economics 14, no. 2 (April 1996): 231-53.

Hanushek, Eric A. "Assessing the effects of school resources on student performance: An update." Educational Evaluation and Policy Analysis 19, no. 2 (Summer 1997): 141-64.

Hanushek, Eric A., John F. Kain, and Steven G. Rivkin. "Does special education raise academic achievement for students with disabilities?". National Bureau of Economic Research, Working Paper No. 6690, 1998.

Hanushek, Eric A., and Richard R. Pace. "Who chooses to teach (and why)?" Economics of Education Review 14, no. 2 (June 1995): 101-17.

Hanushek, Eric A., Steven G. Rivkin, and Lori L. Taylor. "Aggregation and the estimated effects of school resources." Review of Economics and Statistics 78, no. 4 (November 1996): 611-27.

Hanushek, Eric A. with others. Making schools work: Improving performance and controlling costs. Washington, DC: Brookings Institution, 1994.

Hoxby, Caroline Minter. "How teachers' unions affect education production." Quarterly Journal of Economics 111, no. 3 (August 1996): 671-718.

Kain, John F., and Daniel M. O'Brien. "A longitudinal assessment of reading achievement evidence from the Harvard/UTD Texas schools project". Paper presented at the Green Center Conference, "Achieving Universal Literacy," University of Texas at Dallas, April 2-4, 1998.

Kain, John F., and Kraig Singleton. "Equality of Educational Opportunity revisited." New England Economic Review (May/June 1996): 87-111.

Kershaw, Joseph A., and Roland N. McKean. Teacher shortages and salary schedules. NY: McGraw-Hill, 1962.

Kirby, Sheila Nataraj, David W. Grissmer, and Lisa Hudson. New and returning teachers in Indiana: sources of supply. Santa Monica: RAND, 1991.

Loeb, Susanna, and Marianne Page. "Examining the link between wages and quality in the teacher workforce". (mimeo), Department of Economics, University of California, Davis, 1998. 
Manski, Charles F. "Academic ability, earnings, and the decision to become a teacher: Evidence from the National Longitudinal Study of the High School Class of 1972." In Public sector payrolls, edited by David A. Wise, 291-312. Chicago: University of Chicago Press, 1987.

Muranane, Richard J., and Randall Olsen. "The effects of salaries and opportunity costs on length of stay in teaching: Evidence from Michigan." Review of Economics and Statistics 71, no. 2 (May 1989): 347-52.

---. "The effects of salaries and opportunity costs on length of stay in teaching: Evidence from North Carolina." Journal of Human Resources 25, no. 1 (Winter 1990): 106-24.

Murnane, Richard J. "Teacher mobility revisited." Journal of Human Resources 16, no. 1 (Winter 1981): 3-19.

---. "Staffing the nation's schools with skilled teachers." In Improving America's schools: The role of incentives, edited by Eric A. Hanushek and Dale W. Jorgenson, 241-58. Washington, DC: National Academy Press, 1996.

Murnane, Richard J., Judith D. Singer, John B. Willett, James J. Kemple, and Randall J. Olsen. Who will teach? Cambridge: Harvard University Press, 1991.

Niskanen, William A. Bureaucracy and Representative Government. Chicago: Aldine-Atherton, 1971.

---. "Bureaucrats and politicians." Journal of Law and Economics 18, no. 3 (1975): 617-44.

Rivkin, Steven G., Eric A. Hanushek, and John F. Kain. Teachers, schools, and academic achievement. National Bureau of Economic Research, Working Paper No. 66911998.

Rumberger, Russell W. "The impact of salary differentials on teacher shortages and turnover: The case of mathematics and science teachers." Economics of Education Review 6, no. 4 (1987): 389-99.

Strauss, Robert P. Public school teachers in Pennsylvania: Demand and supply through school year 2000. Carnegie-Mellon University (mimeo), 1993.

---. "Teacher preparation and selction in Pennsylvania: Ensuring high performance classroom teachers for the 21st century". (mimeo) Heinz School of Public Policy and Management, Carnegie-Mellon University, 1998.

van der Klaauw, Wilbert. "The supply and early careers of teachers". (mimeo), New York University, 1997.

Weaver, W. Timothy. America's teacher quality problem: Alternatives for reform. New York: Praeger, 1983.

Zarkin, Gary A. "Occupational choice: An application to the market for public school teachers." Quarterly Journal of Economics 100, no. 2 (May 1985): 409-46. 
Appendix Table A1. Multinomial Logit Estimated Effects of Teacher Salary and Student Demographic Characteristics on the Probabilities that Teachers switch School Districts or Exit Teaching (t statistics in parentheses, remaining in the same district is the numeraire)

\begin{tabular}{c}
\multicolumn{3}{c}{ teacher experience } \\
$0-2 \mathrm{yrs} \quad 3-5 \mathrm{yrs} \quad 6-10 \mathrm{yrs} \quad 11-30 \mathrm{yrs} \quad>30$ years \\
\hline
\end{tabular}

Switch Districts

$\begin{array}{lllllc}\log \text { base year } & -1.80 & -2.00 & -1.70 & -1.48 & -2.96 \\ \text { salary } & {[-5.26]} & {[-4.32]} & {[-3.52]} & {[-3.26]} & {[-0.66]}\end{array}$

Campus Average Student Characteristics

$\begin{array}{lccccc}\text { Test Score } & -0.07 & -0.40 & -0.11 & -0.16 & -1.68 \\ & {[-0.92]} & {[-3.84]} & {[-0.97]} & {[-1.43]} & {[-2.05]} \\ & & & & & \\ \text { \% elig. for } & 0.46 & -0.08 & 0.27 & 0.39 & 0.49 \\ \text { subs lunch } & {[2.87]} & {[-0.38]} & {[1.15]} & {[1.81]} & {[0.29]} \\ & & & & & \\ \text { \% Black } & 1.05 & 0.86 & 0.86 & 0.91 & -1.01 \\ & {[6.51]} & {[3.78]} & {[3.47]} & {[3.69]} & {[-0.49]} \\ & & & & & \\ \text { \% Hispanic } & 0.13 & 0.50 & 0.29 & 0.22 & -0.77 \\ & {[0.76]} & {[2.17]} & {[1.14]} & {[0.91]} & {[-0.37]} \\ \text { Interactions with Race/ethnicity of Teacher } & & & & \\ \text { Black* } & -2.81 & -1.58 & -2.01 & -2.22 & 4.22 \\ \text { \% Black } & {[-7.02]} & {[-2.77]} & {[-3.87]} & {[-5.25]} & {[0.59]} \\ \text { Black* } & -1.32 & -0.06 & -0.49 & -1.59 & 3.04 \\ \text { \% Hispanic } & {[-2.94]} & {[-0.11]} & {[-0.96]} & {[-3.58]} & {[0.38]} \\ \text { Hispanic * } & -1.35 & -1.04 & -0.87 & 0.01 & -1.22 \\ \text { \% Black } & {[-3.20]} & {[-1.78]} & {[-1.22]} & {[0.02]} & {[-0.22]} \\ \text { Hispanic * } & -1.15 & -1.10 & -0.71 & -0.80 & -1.77 \\ \text { \% Hispanic } & {[-5.40]} & {[-4.17]} & {[-2.15]} & {[-2.66]} & {[-0.76]}\end{array}$


Table A1 (continued)

\section{Exit Teaching}

$\begin{array}{lllccc}\log \text { base year } & -0.75 & -0.29 & 0.30 & -0.13 & 0.92 \\ \text { salary } & {[-3.44]} & {[-1.09]} & {[1.20]} & {[-0.72]} & {[1.36]}\end{array}$

Campus Average Student Characteristics

$\begin{array}{lccccc}\text { Test Score } & -0.24 & -0.19 & -0.35 & -0.31 & -0.27 \\ & {[-5.22]} & {[-3.26]} & {[-6.35]} & {[-7.71]} & {[-2.04]} \\ & & & & & \\ \text { \% elig. for } & -0.14 & -0.19 & 0.00 & 0.42 & 0.04 \\ \text { subs lunch } & {[-1.47]} & {[-3.26]} & {[-6.35]} & {[5.26]} & {[0.15]} \\ & & & & & \\ \text { \% Black } & 0.59 & 0.43 & 0.08 & 0.05 & -0.52 \\ & {[5.86]} & {[3.37]} & {[0.68]} & {[0.56]} & {[-1.52]} \\ & & & & & \\ \text { \% Hispanic } & 0.20 & 0.22 & -0.14 & -0.30 & -0.49 \\ & {[1.94]} & {[1.71]} & {[-1.15]} & {[-3.33]} & {[-1.56]} \\ \text { Interactions with Race/ethnicity of Teacher } & & & & \\ \text { Black * } & -1.20 & -1.05 & -0.58 & -0.58 & 0.45 \\ \text { \% Black } & {[-5.99]} & {[-4.05]} & {[-2.56]} & {[-4.32]} & {[1.20]} \\ & & & & & \\ \text { Black* } & -0.71 & -0.30 & -0.38 & -0.47 & 0.57 \\ \text { \% Hispanic } & {[-3.04]} & {[-1.06]} & {[-1.53]} & {[-3.39]} & {[1.64]} \\ \text { Hispanic * } & -0.58 & 0.02 & -0.19 & -0.84 & 2.25 \\ \text { \% Black } & {[-2.14]} & {[0.06]} & {[-0.54]} & {[-2.99]} & {[1.57]} \\ \text { Hispanic * } & -0.42 & -0.29 & -0.47 & -0.61 & 0.49 \\ \text { \% Hispanic } & {[-2.85]} & {[-1.62]} & {[-2.78]} & {[-5.00]} & {[0.80]}\end{array}$


Appendix Table A2. Descriptive Statistics - Means and Standard Deviations 4th Grade 5th Grade

Achievement Gains

Math

$-0.02$

0.01

Reading

$(0.65)$

$(0.59)$

$-0.03$

0.01

$(0.67)$

Log District Salary

0 yrs experience

10.00

10.00

(0.11)

(0.10)

Teacher Experience Distribution

$\% 0$ years

6.2

5.7

$\% 1$ year

5.8

5.8

$\% 2$ years

5.1

5.6

$\%$ 3-4 years

11.7

10.8

$\%$ 5-9 years

21.4

19.7

$\%$ 10-19 years

30.9

31.0

$\%$ 21-30 years

16.4

18.6

$\%>30$ years

2.5

2.8

Teacher Transition Distribution from Prior Year

$\%$ same campus \& grade

67.6

66.8

$\%$ same campus, different grade

12.8

11.6

$\%$ different campus, same district

4.2

5.6

$\%$ different district

3.6

3.3

$\%$ not in Texas public schools

11.7

12.7

Student Demographic Characteristics

$\%$ Black

14.1

14.0

(20.4)

(20.4)

$\%$ Hispanic

31.0

31.0

(30.0)

(30.2)

$\%$ Eligible for subsidized lunch

46.8

46.7

(27.1)

(27.0) 